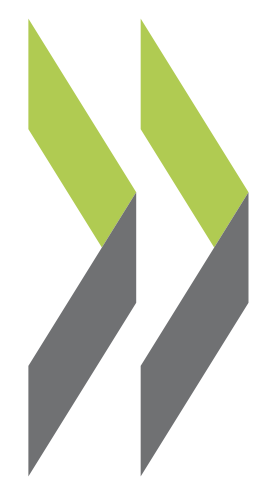

OECD Economics Department Working Papers No. 436

Getting the Most Out of Public Sector Decentralisation in Spain

Isabelle Joumard, Claude Giorno 
Organisation de Coopération et de Développement Economiques

Organisation for Economic Co-operation and Development

21-Jul-2005

ECONOMICS DEPARTMENT

English - Or. English

GETTING THE MOST OUT OF PUBLIC SECTOR DECENTRALISATION IN SPAIN

ECONOMICS DEPARTMENT WORKING PAPER No. 436

by Isabelle Joumard and Claude Giorno

All Economics Department Working Papers are now available through OECD's Internet web site at http://www.oecd.org/eco. 


\section{ABSTRACT/RÉSUMÉ}

\section{Getting the most out of public sector decentralisation in Spain}

In about two decades, Spain was transformed from one of the most centralised countries to one of the most decentralised. Spending functions were devolved rapidly. The regions have exercised their discretionary powers quite extensively and innovative policies have been implemented. But devolution was also accompanied by a hike in public employment and pressures on public spending, reflecting duplication in resources and poor co-ordination across and between government levels. The recent devolution of taxing powers could raise the accountability of the regions and, thus, cost-consciousness, although their effective use has been limited. Securing fiscal discipline would require better information on sub-national governments' policies and outcomes so as to allow citizens to press for improved performance. The financing system of the regions also needs to be reformed to ensure sustainability in the face of changing demographics, while the fiscal rules need to be upgraded to avoid recourse to off-budget operations.

This Working Paper relates to the 2005 OECD Economic Survey of Spain (www.oecd.org/eco/surveys/spain).

JEL classification: $\mathrm{H} 1, \mathrm{H} 2, \mathrm{H} 4, \mathrm{H} 5, \mathrm{H} 7$

Keywords: Fiscal federalism, sub-national government, intergovernmental grants, fiscal discipline, fiscal rules, Spain.

$$
* * * * * * *
$$

\section{Optimiser l'impact de la décentralisation en Espagne}

En l'espace de deux décennies, l'Espagne, qui était l'un des pays les plus centralisés, est devenue l'un des plus décentralisés. Les compétences en matière de dépenses ont été transférées rapidement. Les régions ont souvent été innovantes, adaptant leur offre de services publiques aux préférences locales. Toutefois, ces transferts se sont aussi accompagnés d'une hausse de l'emploi public et de pressions sur les dépenses publiques, ce qui reflète une duplication des ressources et un manque de coordination à chaque niveau d'administration et entre les différents niveaux. Le récent transfert de pouvoirs fiscaux aux régions pourrait renforcer leur responsabilité, et donc leur souci de maîtriser les coûts, bien qu'elles n'aient que peu utilisé ces pouvoirs. Assurer la discipline budgétaire nécessiterait une information plus complète sur les politiques et les résultats des administrations territoriales afin que les citoyens puissent réclamer une amélioration des performances. Il faut aussi réformer le système de financement des régions pour en assurer la viabilité face aux changements démographiques, tandis que les règles budgétaires devraient être ajustées de façon à éviter le recours aux opérations extrabudgétaires.

Ce Document de travail se rapporte à l'Etude économique de l'OCDE de l'Espagne, 2005 (www.oecd.org/eco/etudes/espagne).

Classification JEL : H1, H2, H4, H5, H7

Mots clés : Fédéralisme financer, collectivités territoriales, transferts intergouvernementaux, discipline budgétaire, règles budgétaires, Espagne.

Copyright OECD, 2005

Application for permission to reproduce or translate all, or part of, this material should be made to: Head of Publications Service, OECD, 2 rue André Pascal, 75775 Paris Cedex 16, France. 


\section{TABLE OF CONTENTS}

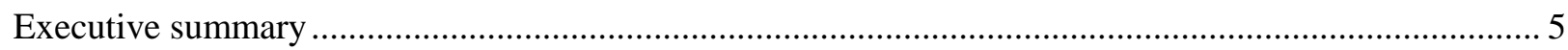

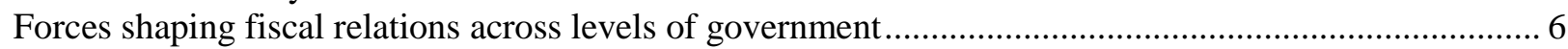

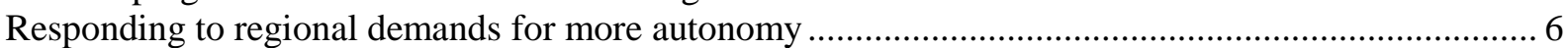

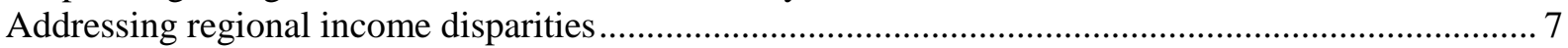

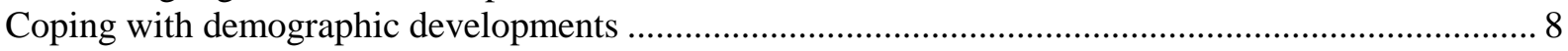

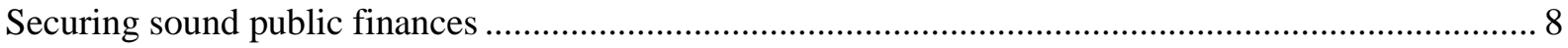

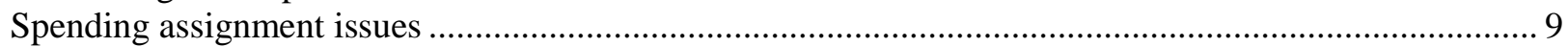

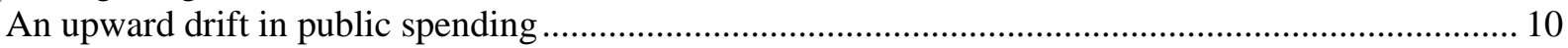

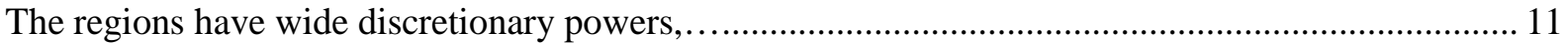

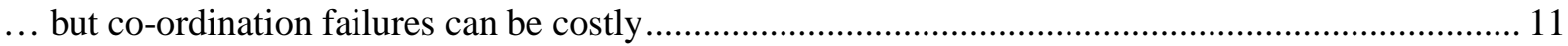

The case for transferring responsibilities to the municipalities is mixed.......................................... 15

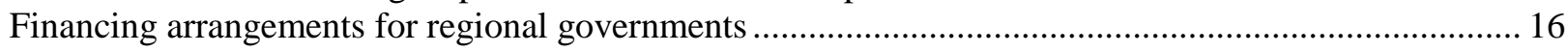

The regions are now less dependent on grants and have more revenue-raising powers........................ 16

There is not enough flexibility to account for demographic developments......................................... 20

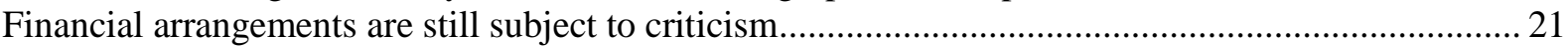

Existing financial arrangements may make it difficult to cope with future spending pressures............ 22

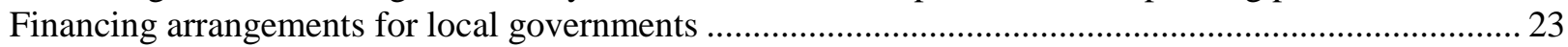

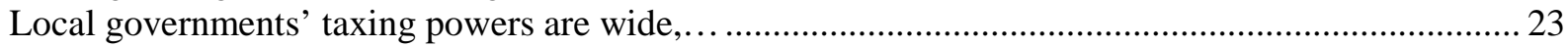

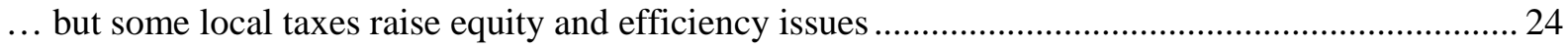

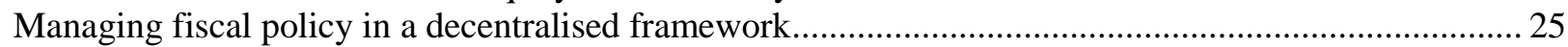

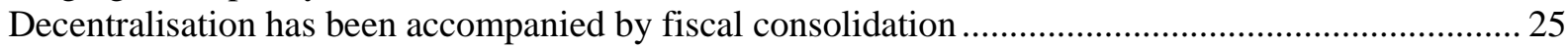

The new Fiscal Stability Law is designed to preserve fiscal discipline ................................................ 27

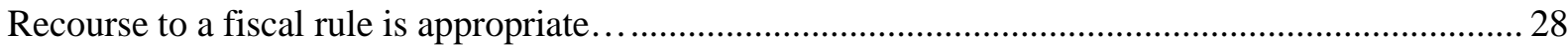

... but the FSL's excessive rigidity could have a destabilising macroeconomic effect....................... 29

$\ldots$ and to foster the growth of off-budget operations detrimental to transparency................................. 30

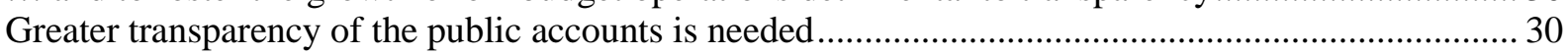

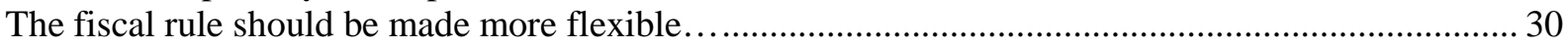

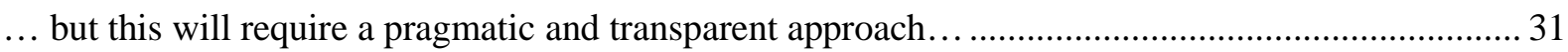

... which needs to balance the specific regional requirements and those of the whole country............ 31

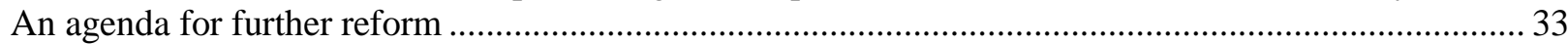

Develop information systems on sub-national government policies and performance ......................... 34

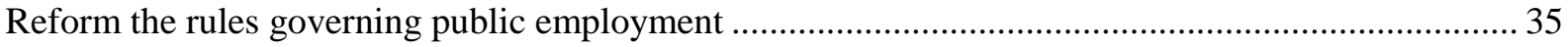

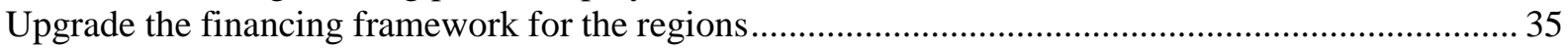

Reform local government taxes and be prudent in transferring new spending responsibilities............. 36

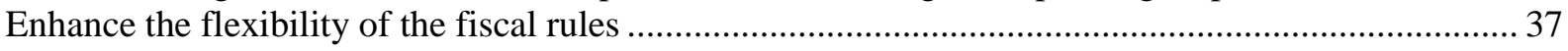

Annex A1. Recent reforms of the local government financing system ................................................. 42

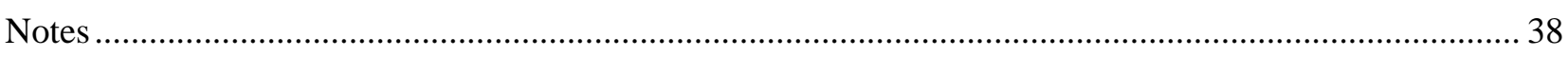

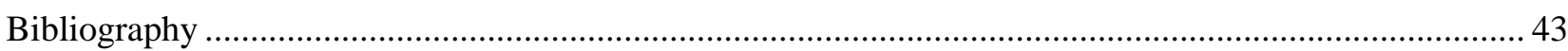




\section{Boxes}

1. Spending assignment across levels of government ......................................................................... 9

2. Transfer of responsibilities for health care management and its financing ....................................... 14

3. Main features of the 2002 financing arrangement for common regime regions .................................. 17

4. Main features of the Foral system for País Vasco and Navarra ........................................................ 21

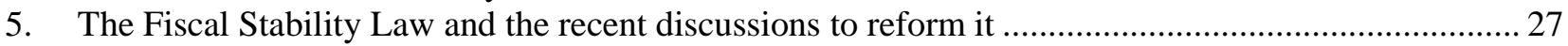

6. Recommendations for improving fiscal relations across levels of government ................................ 33

\section{Figures}

1. Sub-national government share in general government revenues and expenditure

2. Regional dispersion in GDP per capita in OECD countries

3. Spending and employment by level of government

4. Tax revenue by government level

5. Regional distribution of central government investment and earmarked grants

6. Local government financial resources in selected OECD countries

7. Recurrent taxes on immovable property in OECD countries

8. Public debt by level of government

9. Government financial balances

10. Regional debt and deficits

11. Government investment and the economic cycle

12. Debt share of public enterprises

13. Regional gap differences from the country average

\section{Tables}

1. Health care spending and resources by region

2. The size of municipalities in Spain and several EU countries

3. Regional governments' main tax resources before and after 2002

4. The use of regional governments' discretionary powers for personal income tax 
ECO/WKP(2005)23

\title{
GETTING THE MOST OUT OF PUBLIC SECTOR DECENTRALISATION IN SPAIN
}

\author{
by Isabelle Joumard and Claude Giorno ${ }^{1}$
}

\section{Executive summary}

1. Following the rapid decentralisation to the regions since the early 1980s, the sub-national authorities now have more staff to manage than does central government and have responsibility for spending on education, the social services and health. Decentralisation has not compromised fiscal stability so far, and has enabled regional governments to provide better-tailored services. Nevertheless, it has also resulted in a rapid increase in government employment, and has undermined cost-effectiveness in a number of domains, creating pressures on public spending. Rapid decentralisation has, for instance, been accompanied by a fragmentation and a loss of information. Sub-national government accounts are available only with a significant lag and the use of off-budget operations through public enterprises controlled by the regions or municipalities has expanded. In addition, although anecdotal evidence suggests that regional governments have implemented innovative policy options in some areas, in particular health care, there is a lack of consistent and reliable information on such policies and outcomes. Thus, the diffusion of best practice is limited, the lack of co-ordination between and across levels of government results in an inefficient use of public facilities, while citizens cannot easily benchmark their own governments against others and press for a more efficient public sector. Developing proper information systems on sub-national governments' policies and outcomes would support fiscal discipline.

2. The new financing arrangement for the regions is commendable in many respects. Most importantly, it has brought the regions' revenue-raising powers more in line with their spending responsibilities and intergovernmental transfers have been redesigned so as to mitigate moral hazard problems. It should thus contribute to secure fiscal discipline at the regional level. Although the new financing arrangement is rather recent, the government is currently assessing its implementation, and a discussion on some of its main features is underway within the Council for Fiscal and Financial Policy, where both the central government and the regions are represented. To deliver its full benefits, the new financing model should make fully operational its mechanisms to make it sustainable in the face of demographic developments, in particular immigration and the prospect of population ageing. A careful examination of the best approach to finance the likely increase in regional spending over the long term because of population ageing should be carried out, with the objectives of: avoiding large distortion associated with labour taxes; underpinning regional governments' incentives to act in a cost-conscious way; and ensuring that regional governments' revenue raising powers are used and adequate to deliver a sufficient standard of public services to all citizens. In addition, the redistributive bias in allocating central government investment across the regions should be reconsidered, as distributive goals can be achieved by better instruments. At the municipal level, the existence of many very small municipalities argues in favour of a cautious approach to the transfer of new spending responsibilities. Their financing should however be improved by reconsidering the local business tax, which is paid only by relatively large companies and could hinder the growth of enterprises or create a risk of tax avoidance, while increasing local governments' reliance on the real estate tax. This would require upgrading the land and property register. 


\section{ECO/WKP(2005)23}

3. To maintain fiscal discipline in the decentralised framework, a Fiscal Stability Law was implemented in 2003 with the objective of keeping the accounts of all levels of government, taken individually, permanently in balance. While it has the advantage of being simple and easy to convey, this rule is nevertheless formulated in too rigid a manner and could result in fiscal policy playing a pro-cyclical role. The government is envisaging amending the fiscal rule so as to better account for cyclical conditions. The central government and the regions taken collectively will be allowed to post deficits during cyclical troughs but will be required to produce surpluses when activity is buoyant. In the case of the local authorities, on the other hand, changing the present system does not appear necessary because their budgets are not very sensitive to the economic situation whereas maintaining structural surpluses would be preferable in the case of the social security system. The specific sharing of overall fiscal targets between the different regions needs to be based on a consensual approach of collective surveillance so as to avoid having to resort to sanction mechanisms which appear difficult to implement. It would nevertheless be worthwhile continuing to require the regions to present a medium-term fiscal adjustment plan in the event that they significantly miss their targets. It is vital to ensure that the new norm does not de facto weaken fiscal discipline and that it is applied equitably to all the regions, whatever their size.

\section{Forces shaping fiscal relations across levels of government}

\section{Responding to regional demands for more autonomy}

4. Demands for greater regional autonomy, which have led to a rapid decentralisation over the recent years (Figure 1), have been spurred by a long history of asymmetric federalism. The so-called Foral system, which dates back to the $18^{\text {th }}$ century, gives País Vasco and Navarra significant autonomy. They have wide-ranging discretionary powers to set tax bases and rates (value added tax [VAT] being the notable exception), collect most of them and remit a payment to the central government for the services it provides. And in País Vasco, the regional government is now pressing for even greater autonomy. ${ }^{2}$ The other 15 regions, known as "common regime regions", have less autonomy, in particular in setting and collecting taxes. Spending responsibilities across common regime regions also varied significantly from the late 1970s to 2002, when the devolution of the health and education systems was completed. The Foral regions contribute less to fiscal equalisation schemes than the common regime regions. This asymmetric federalism has nurtured demands for more autonomy in regions with a strong regional identity (in particular Cataluña) and has challenged intergovernmental transfer schemes. At the same time, the role of the regional representatives has grown significantly over the past decade, although not directly through the upper chamber (the senate). Since 1993, political parties elected to govern have had an absolute majority in Parliament for only four years and have had to win the support of regional nationalist parties, in particular from Cataluña, País Vasco and, to a lesser extent, from Canarias. ${ }^{3}$ 
ECO/WKP(2005)23

Figure 1. Sub-national government share in general government revenues and expenditure ${ }^{1}$

Per cent, $2002^{2}$

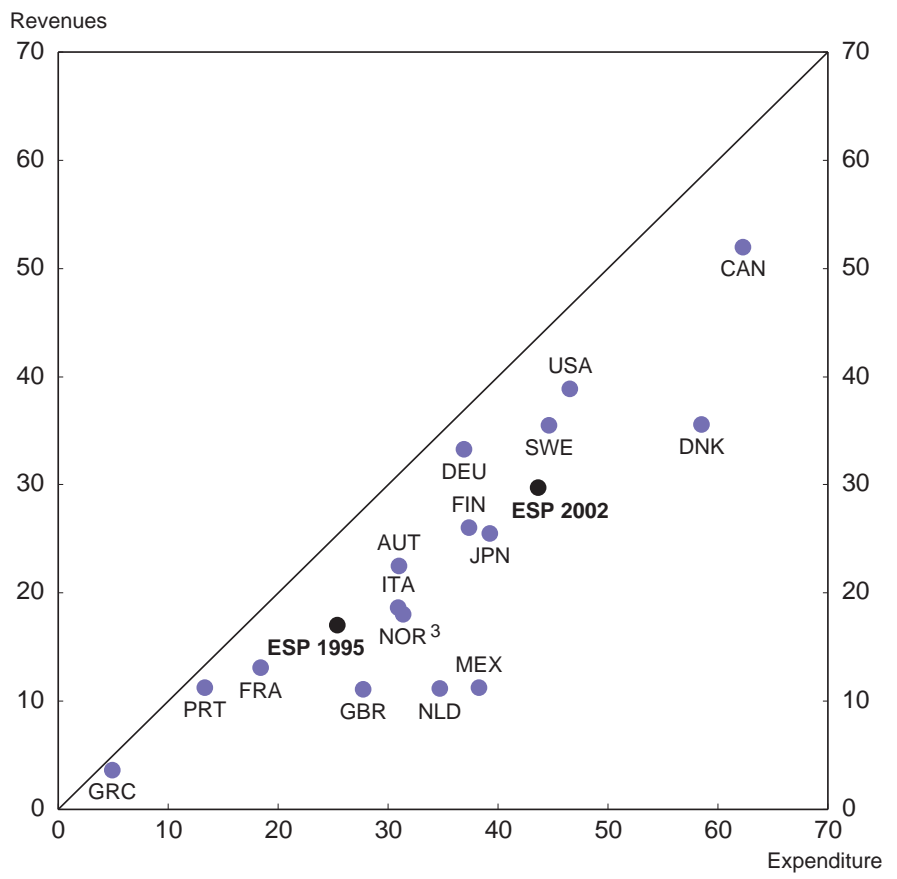

1. Revenues include direct and indirect taxes as well as non-tax revenues received by regional and local governments and are expressed as a share of revenues received by the general government. Expenditure corresponds to total expenditure by regional and local governments expressed as a share of general government expenditure. Transfers between governments are netted out. The country ranking in this figure does not necessarily correspond to the comparative fiscal autonomy of sub-national governments.

2. Or latest year available: 2000 for Japan and Mexico, 2001 for Portugal.

3. Mainland only. Data exclude revenues from oil production.

Source: OECD, National Accounts; Statistics Norway; Statistics Canada; US Bureau of Economic Analysis.

\section{Addressing regional income disparities}

5. Reducing income disparities and promoting a balanced development throughout the country are important policy objectives. Income disparities across regions have declined, albeit slowly (de la Fuente et al., 2003a), and were narrower than in many other OECD countries in 2001 (Figure 2). Central government efforts to develop infrastructure in low-income regions and EU structural funds have played a role in fostering convergence. Total structural fund expenditure accounted for $3.8 \%$ of the aggregate output of the Objective 1 regions in Spain over the period 1994-99, for almost 50\% of the total spending on infrastructure and $13.8 \%$ of other investment in physical capital (de la Fuente, 2003). EU enlargement will likely entail that some regions will no longer qualify for Objective 1 funding as of 2007 since their GDP per capita has moved above the EU-wide 75\% income threshold. At the same time, existing fiscal rules imposed on sub-national governments, by limiting recourse to indebtedness, may impinge on sub-national investment. This situation will likely require exploiting opportunities to raise public spending efficiency at the sub-national level, so as to provide some room to finance investment needs from existing resources. ${ }^{4}$ 
Figure 2. Regional dispersion in GDP per capita in OECD countries

Gini index, $2001^{1}$

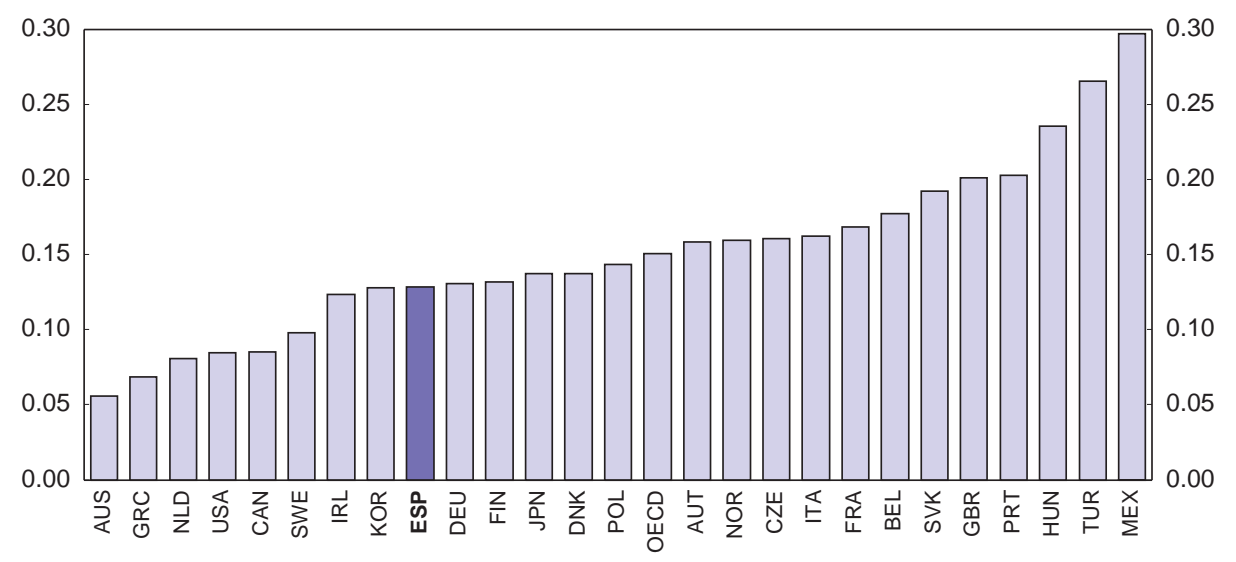

1. Gini coefficient with GDP per capita in NUTS3 territorial units weighted by population. 2000 data for Mexico, Norway and Turkey.

Source: OECD (2004), OECD Regions at a Glance, forthcoming.

\section{Coping with demographic developments}

6. Migration and ageing will have significant fiscal consequences on sub-national governments and create funding tensions. Immigration has increased dramatically since the late 1990s. The number of foreigners on municipal registers (padrón) reached 3.1 million in 2004, more than four times the 1999 level. Some regions have attracted most of this inflow - in 2003 the proportion of foreigners reached $9 \%$ or more of the population in Baleares, Canarias, Comunidad Valenciana, Madrid and Murcia, compared with $6.2 \%$ for Spain as a whole. ${ }^{5}$ Internal migration flows, although very low by international comparison, are adding some momentum, with some regions experiencing a constant decline in population. These demographic developments have had a significant impact on the demand for public services funded by the regions (in particular health care and education, to which foreigners are given free access as soon as they are registered in a municipality). Ageing populations will also create significant spending pressures. Health and long-term care services are funded by the regions and spending is projected to increase steadily as the population ages. Raising the female participation rate - one of the objectives of the central government will require developing elderly and child care services, two areas in which Spain is clearly lagging behind most other EU countries. All these considerations call for a reassessment of the existing funding principles for the regions, in particular to ensure that sub-national governments' revenues adjust adequately to demographic developments, and to avoid too distortive adjustments in sub-national taxes.

\section{Securing sound public finances}

7. In a highly decentralised setting, strengthening fiscal co-ordination across levels of government is of paramount importance to ensure that the overall fiscal framework does not unduly restrain the growth potential of the economy. While the progress made with fiscal consolidation since the mid-1990s is impressive and the tax-to-GDP ratio relatively low, demands for increasing social spending are accumulating and the fiscal impact of population ageing is projected to be large. Balanced budget rules have been imposed on sub-national governments. But allowing a role for automatic stabilisers, avoiding recourse to fiscal gimmickry and ensuring that public investment does not bear most of the brunt during downturns remain important concerns. In addition, by targeting fiscal balances, existing fiscal rules do not directly restrain public spending, leading to the risk of a rise in sub-national taxes with potential adverse 
effects for the economy as a whole. Creating the appropriate incentives for sub-national governments to improve the cost-effectiveness of spending should be a priority. The strengthening of peer and competitive pressures across sub-national governments, as well as the design of intergovernmental grants are, in this regard, important instruments.

\section{Spending assignment issues}

8. The devolution of spending responsibilities to the regions has been rapid and far-ranging since the early 1980s (Box 1). It comprised the two largest public spending items after pensions, namely education and health care. In addition, social assistance - which the 1978 Constitution already placed under regional control - has gained in importance. Overall, the share of the regions in total public spending rose from $14 \%$ in 1985 to $31 \%$ in 2002, a high share compared with most other federal OECD countries (Figure 3, panel A). Devolution has had positive features but some thorny issues have also arisen. To illustrate them, this section covers two sectors in more detail: health care - which amounts to $35 \%$ of regional government spending - and active labour market policies (ALMPs) - which have an important role to play in a country with a still high unemployment rate.

\section{Box 1. Spending assignment across levels of government}

All regions now have broadly the same responsibilities as regards the delivery of public goods and services, after two decades of asymmetric federalism - some regions took over responsibilities much earlier than others, e.g. for health care, ALMPs or education. The Constitution enumerates the powers that may be adopted by the regions (Article 148) and those which are an exclusive competence of the central government (Article 149):

- $\quad$ Article 148 lists the 22 functions over which regions may assume regulatory and executive responsibilities. These include: urban regulation, housing, regional infrastructure (railways and highways which are confined to the territory of the region, recreational ports, airports and water infrastructure in its territory), health care and social assistance. The devolution of health care responsibilities began in 1981. By 1995, seven regions, out of 17, had taken over this responsibility. The devolution of health care to all regions was completed in 2002. In addition, each region may take over the responsibility for delivering specific services as long as it does not conflict with central government's prerogatives.

- Article 149 of the Constitution concerns the central government's exclusive responsibilities to legislate and execute. ${ }^{1}$ It also recognizes that some of them may be implemented in tandem with the regions. These include: labour market policies, civil service status and compensation conditions, social security, education, environment and public security. Article 150 of the Constitution further acknowledges that some of the central government's responsibilities may be transferred or delegated to the regions. In particular, responsibilities for managing training programmes for both the unemployed and the working population have gradually been transferred to the regions, starting in 1992, although the central government still issues the National Vocational Training and Insertion Plan and sets criteria for those workers who will undergo training. Similarly, the overall organisation of the education system, the regulation of academic and professional titles and school inspection is under the central government. Some operational responsibilities (e.g. decision on the number of teachers, some recruitment criteria and specific compensation elements) were transferred to seven regions in the 1980s and for the other regions the transfer was completed in 1997. Part of the curriculum content is also under the responsibility of the regions.

Local government responsibilities are not enumerated in the Constitution; they are defined in the Local Government Act of 1985. They vary with the size of municipalities. All municipalities are responsible for: public lights, cemeteries, water supply, sewerage, waste management, paved roads, urban planning and building control, food and beverage control. Municipalities with a population over 5000 must provide public parks, a library, a market place and solid waste treatment. Municipalities with a population over 20000 have to provide social services, fire fighting, sport facilities and slaughterhouses. Municipalities with a population over 50000 must provide urban public transportation and environmental protection services. Services which are not provided by smaller municipalities can be made available to citizens through specific co-operative arrangements managed at the regional level.

1. These include: justice, defence, foreign affairs, constitutional rights, national infrastructure (transport and water infrastructure that runs through more than one region; ports and airports of general interest), academic degrees and health service standards. The Constitution also puts basic regulation and co-ordination of health care, as well as legislation on pharmaceutical products, fully under central government's responsibility. 
Figure 3. Spending and employment by level of government
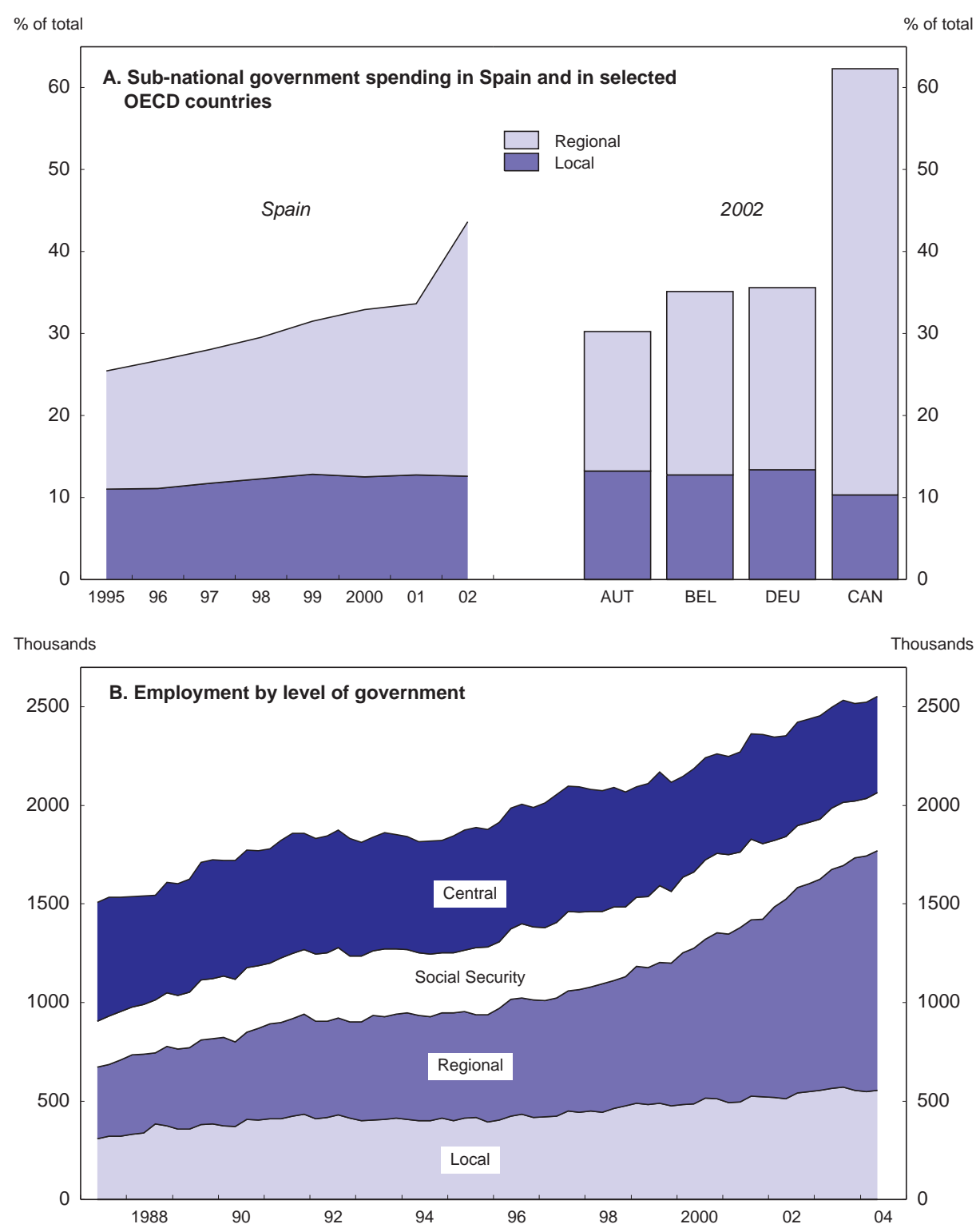

Source: INE and OECD National Accounts.

9. The functions of the municipalities have changed little over the past 25 years. However, a debate on decentralisation to the municipal level (Pacto local) is under way, even though there is not yet an agreement on the functions which could be best performed at this level. With rather small municipalities, the existence of economies of scale should be an important factor in shaping reform. 
ECO/WKP(2005)23

\section{An upward drift in public spending}

10. The rapid decentralisation has created pressures on public spending, with some duplication of tasks and a loss of cost-effectiveness in a number of domains. Experience to date, similar to that in other OECD countries (in particular Italy), has shown that territorial transfer of personnel is difficult. General government employment has risen by almost $70 \%$ since 1987, much faster than in virtually all other OECD countries, with employment creation at the regional level, and to a lesser extent at the municipal level, far outpacing the decline at the central level (Figure 3, panel B). ${ }^{6}$ Although the rise in the coverage of key services (e.g. the increase in school enrolment) has played a role, there are also indications that regional employment needs have not been entirely covered by transfers of employees from the central government (Marqués Sevillano and Roselló Villalonga, 2002).

11. The central government imposes a limit on the increase in the number of permanent employees at the sub-national level and sets basic salaries for civil servants as well as their annual adjustment, be they employed by the central or sub-national governments. ${ }^{7}$ Sub-national governments, however, do have some flexibility to set performance-based elements for permanent employees and have increasingly relied on temporary job contracts which offer more flexibility in terms of both employment and compensation levels. Between 1997 and 2004, 56\% of total public employment contracts were temporary job contracts. In mid-2004, 23\% and 30\% of regional and local government employees, respectively, had a temporary work contract, compared with $13 \%$ at the central level (CES, 2004). The proportion of temporary contracts varies also quite widely across regions (i.e. from less than 13\% in La Rioja to $33 \%$ in Extremadura) and is higher in smaller municipalities (less than 20000 inhabitants) than larger ones. Significant variations in compensation levels have also arisen. A recent study for the health care sector revealed that, for a similar position, compensation can vary by up to $43 \%$ across regions, creating labour shortages and wage pressures in the less "generous" regions."

\section{The regions have wide discretionary powers,...}

12. Sub-national governments have significant discretionary powers in a number of domains allowing them to implement innovative policy options. The health care sector provides many examples of regional pilot programmes. Regional governments' efforts to contain pharmaceutical costs $-e$.g. by regulating doctors' prescription practices and/or reimbursement conditions - and to reduce public hospital waiting lists have been numerous and some have proved to be successful. ${ }^{9}$ Other initiatives have tended to increase health care spending, such as the decision by Andalucía and Navarra to reimburse drugs included on the negative list established by the central government. Regional governments have also taken the lead in designing and implementing anti-poverty programmes (de Ayala Cañón et al., 2001). In particular, regional governments have complete autonomy to set the level and eligibility criteria for the minimum income assistance schemes, which do differ significantly across regions. In the education sector, the Ministry of Education establishes the minimum curriculum content but still leaves $35 \%$ to $45 \%$ of the curriculum under the responsibility of sub-national governments (depending on regional language requirements). In sharp contrast, conditions for managing active labour market policies seem rather strict. Obtaining funding (the share of social security contributions earmarked for training is $0.7 \%$ of the wage bill) requires regional governments to pay providers at a price set by a 1993 royal decree. Some regional governments consider these amounts too low to find suitable providers, in particular since they are not allowed to top up this amount.

\section{... but co-ordination failures can be costly}

13. The rise in sub-national government spending reflects not only citizens' preferences and structural trends (in particular for health care) but also a lack of co-ordination across and between government levels. 


\section{Too little sharing of experience and lack of benchmarking}

14. The lack of consistent and reliable information on sub-national government policies and outcomes has weakened the benefits of decentralisation. While regional governments have carried out many policy experiments, obtaining information on them and their outcomes is arduous. Although there are some ad hoc, bilateral, discussions across regions and between the regions and respective ministries, most observers recognise that the sharing of good and bad experiences at the sub-national level is too limited and informal.

15. Citizens do not have access to a consistent set of information to assess the policies of their government, benchmark them against others and thus press for a more efficient public sector. Examples include: the absence of a standardised measure for hospital care waiting lists or student learning achievements and the parsimonious information on eligibility conditions and user charges applied by the regions for elderly care. ${ }^{10}$ This contrasts with the practice in several other decentralised countries. The Norwegian experience in this domain stands out: Statistics Norway, which is recognised for its independence and impartiality, collects information on the quantity and quality of services provided by each municipality (such as elderly care facilities and number of adults per dependent person), as well as prices, tax parameters and the fiscal position. All this information is available on the internet. The Danish government has recently announced that it will set up an evaluation unit to benchmark local government performance in various areas with the objective of lifting average performance by naming and shaming the weakest performers.

\section{Co-ordination failures: the case of decentralised ALMPs}

16. In a fragmented government system, lack of co-ordination can weaken the effectiveness of public policies. Since the mid-1980s, the responsibility for managing ALMPs has been gradually transferred to the regions, including training programmes as well as job matching functions, while the central government remains in charge of regulating and managing unemployment benefits. ${ }^{11}$ The lack of co-ordination in the information system for job vacancies and demands has, however, reduced the efficiency of labour market policies. Because the system used by some regions is not compatible with that of the central government, it has been difficult to fill job offers in some regions, hampering labour mobility (CES, 2000). Although this problem was already identified in 2000, the implementation of an integrated job database (SISPE) was only completed at the end of 2004.

17. The separation between active and passive policies may have weakened the regions' incentives to implement more effective policies to reduce unemployment. Under the current set-up, the regions do not receive the fiscal windfall of a reduction in unemployment - the decline in unemployment benefits the central government. They may, however, receive less grant income from the central government since the criterion to allocate funds across regions is the number of unemployed. A carousel effect could also develop as suggested by the experience in Canada and Switzerland which are among the few countries where spending and financing arrangements for labour market policies are broadly similar to Spain. Partial evidence in these two countries suggests that in some cases, ALMPs are not designed to promote employability but rather to place recipients into short-term jobs which re-qualify them for unemployment benefits paid by the central government, lightening the fiscal burden of social assistance programmes paid by the Canadian provinces or Swiss cantons. ${ }^{12}$ In Spain, there is no evidence of such a carousel effect but similar concerns have arisen for disability benefits (OECD, 2003a). The regions may have an incentive to shift case-loads from social assistance (which they pay for) onto non-contributory disability, which they administer, but do not pay for. 


\section{There is too little co-operation among sub-national governments}

18. Decentralisation has resulted in duplication as there is little incentive to engage in co-operative arrangements between regions. The health care sector provides an illustration. Disparities in resources across regions were significant when the devolution in health care was completed in 2002, with endowments in facilities and personnel well below the national average for instance in Castilla-La Mancha while others, such as Aragón and Madrid, were in an enviable position (Table 1). The 2001 reform of funding arrangements (Box 2) recognised these disparities and set the regions' entitlements to central government grants in an asymmetric way. It increased financial resources for those regions with low health costs and less developed facilities significantly but maintained higher transfers for those with high costs. It also required regional governments to spend on health care a minimum amount, based on the financing needs set for the 1999 base year (which are updated according to the criteria listed in Box 2). The whole resources of the financing system are conditional on the regions' spending the minimum amount. As a result, spending in regions with low costs has increased steadily. As an illustration, Castilla-La Mancha is building four new hospitals and raising the number of doctors significantly.

Table 1. Health care spending and resources by region

Health care responsibilities assumed by the regions before or during 2002

\begin{tabular}{|c|c|c|c|c|c|c|c|c|}
\hline & \multicolumn{4}{|c|}{ Health care facilities, 2000} & \multicolumn{3}{|c|}{ Financial resources } & \multirow{3}{*}{$\begin{array}{c}\text { Health care } \\
\text { spending, } \\
€ \text { per capita, } \\
2004^{2}\end{array}$} \\
\hline & \multicolumn{3}{|c|}{ For 10000 inhabitants } & \multirow{2}{*}{$\begin{array}{l}\text { X-ray rooms, } \\
\text { for } 1 \text { million } \\
\text { inhabitants }\end{array}$} & \multicolumn{2}{|c|}{$\begin{array}{c}\text { Per capita, } \\
\text { average }^{1}=100\end{array}$} & \multirow{2}{*}{$\begin{array}{l}\text { Cohesion } \\
\text { fund, } \\
\text { thousand } € \text {, } \\
2002\end{array}$} & \\
\hline & $\begin{array}{l}\text { Hospital } \\
\text { beds }\end{array}$ & Personnel & Doctors & & $\begin{array}{l}\text { Previous } \\
\text { system }\end{array}$ & $\begin{array}{l}\text { Current } \\
\text { system }\end{array}$ & & \\
\hline \multicolumn{9}{|l|}{ Before 2002} \\
\hline Andalucía & 32 & 96 & 16 & 75 & 98 & 96 & 0 & 727 \\
\hline Canarias & 52 & 114 & 18 & 89 & 96 & 99 & 0 & 800 \\
\hline Cataluña & 49 & 99 & 20 & 61 & 105 & 103 & 8381 & 657 \\
\hline \multicolumn{9}{|l|}{ Comunidad } \\
\hline Valenciana & 31 & 92 & 18 & 76 & 100 & 98 & 2117 & 672 \\
\hline Galicia & 40 & 100 & 18 & 91 & 101 & 102 & 0 & 691 \\
\hline Navarra & 45 & 135 & 21 & 76 & .. & .. & .. & 846 \\
\hline País Vasco & 42 & 92 & 19 & 81 &.. &.. &.. & 767 \\
\hline \multicolumn{9}{|l|}{ In 2002} \\
\hline Aragón & 48 & 123 & 22 & 83 & 109 & 109 & 0 & 737 \\
\hline Asturias & 42 & 104 & 18 & 106 & 112 & 110 & 3 & 737 \\
\hline Baleares & 45 & 116 & 26 & 109 & 86 & 101 & 0 & 612 \\
\hline Cantabria & 46 & 110 & 18 & 77 & 110 & 121 & 3443 & 820 \\
\hline Castilla-La Mancha & 31 & 84 & 15 & 68 & 97 & 102 & 0 & 743 \\
\hline Castilla y León & 47 & 100 & 18 & 84 & 100 & 104 & 0 & 716 \\
\hline Extremadura & 41 & 95 & 15 & 77 & 102 & 103 & 0 & 768 \\
\hline Madrid & 43 & 120 & 22 & 97 & 95 & 93 & 31176 & 681 \\
\hline Murcia & 36 & 99 & 18 & 67 & 97 & 96 & 0 & 758 \\
\hline La Rioja & 35 & 87 & 13 & 104 & 96 & 123 & 0 & 881 \\
\hline Spain & 41 & 102 & 19 & 80 & 100 & 100 & 45120 & 711 \\
\hline Memorandum item: & & & & & & & & \\
\hline Coefficient of variation & 0.16 & 0.13 & 0.16 & 0.18 & 0.07 & 0.08 & .. & 0.10 \\
\hline
\end{tabular}

1. Excluding País Vasco, Navarra, Ceuta y Melilla.

2. Adjusted for the population age structure, budget data.

Source: Ministerio de Economía y Hacienda; Ministerio de Sanidad y Consumo; INE; R.M. Urbanos (2004), "El impacto de la financiación de la asistencia sanitaria en las desigualdades", in Gaceta Sanitaria, SEPAS, Vol. 18, Supplement 1. 


\section{Box 2. Transfer of responsibilities for health care management and its financing}

Responsibility for health care management was transferred gradually to 7 out of the 17 regions over the period 1981-94. At the time of devolution, a financial agreement had to be reached between the central government, subject to specific contextual and political pressures (European Observatory on Health Care Systems, 2000). This resulted in somewhat heterogeneous criteria for defining the accompanying earmarked transfers, including notably historical costs and the population covered (Ministerio de Sanidad y Consumo, 2003). In 2002, a new financing arrangement was agreed between the central government and the five common regime regions with health care responsibilities before 2002 (País Vasco and Navarra are financed under a different arrangement, see below), comprising a General and a Cohesion Fund to cover the costs of health care services for residents and non-residents.

The General Fund was set by applying two principles:

- It first recognised the amount of health care spending in the five common regime regions in 1999 (the last year for which data were available at the time of the agreement) and allocated this amount across them according to three criteria: population (75\%), population above $65(24.5 \%)$ and island status $(0.5 \%)$. Regions with historical spending below the national average thus received additional funds compared with their previous spending level.

- A "minimum guarantee" was then applied to ensure that no region would lose from the introduction of the new financing arrangement. This basically entailed that regions with high spending received higher per capita transfers compared with the national average.

The remaining ten common regime regions took responsibility of the health care sector in 2002 and bilateral negotiations between each of them and the central government were carried out at that time to set their health care financing needs, mostly on the basis of actual costs.

The agreement also foresaw that for all common regime regions: $i$ ) It creates a guarantee for a minimum growth in the financial resources for health care for the period 2002 to 2004; if financial resources in every year increase less than GDP, the central government will transfer the difference. However, changes in total population or in its demographic characteristics (in particular the share of elderly people) are not taken into account. ${ }^{1}$ ii) Spending on health care should be at least equal to the financial resources recognised by the new financing arrangement for the five common regime regions which had taken over health care responsibility before 2002 and to the amount recognised through bilateral negotiations for the ten others (adjusted over time by the increase in central government tax revenue, the so-called ITE nacional). Any increase in spending above this level is to be financed by the regions from their own revenues, either by reallocating resources or by raising taxes (including by introducing the tax on retail sales on oil products), whose proceeds are earmarked for health care or environmental policy.

A so-called Cohesion Fund was created to cover (part of) the costs of hospital care for non-residents. The compensation received by providing regions is paid fully by the central government but at a level set below the unit cost for services - on the ground that providing regions, being often those with highly specialised care facilities and thus high health care costs, are already entitled to higher transfers since past actual costs have been accounted for when setting their level.

1. Negotiations between the central government and a region could be opened if a region's total population grows by more than 3 percentage points faster than the national average in any given year. Cumulative deviations are, however, not accounted for.

19. While an attractive option to avoid the duplication of specialised services in a context of a high variation in installed capacity across regions, co-operative arrangements in the health care sector have hardly been promoted. Co-operative arrangements could be designed so that, instead of building new facilities, regions with low capacity buy specialised services from a better equipped region. This form of co-operative arrangement has been implemented for hospital services in Italy and in Switzerland and it also applies to other services, in particular tertiary education in Switzerland (Joumard and Giorno, 2002). It has two attractive features: it allows the exploitation of scale economies and introduces some competition if one region can buy services from different suppliers (other regions or private providers). Another argument for co-operative arrangements is the "critical mass effect". For highly specialised health care facilities, safety conditions may deteriorate substantially below a certain threshold of use. Similarly for tertiary education, too low a number of students may reduce network effects, and thus educational outcomes. 
20. The Cohesion Fund was created to compensate regions for providing health care services to nonresidents (either foreign tourists or residents from other Spanish regions). However, it does not create strong incentives for providers to participate in such arrangements since the financial compensation received for non-residents does not cover all costs. On the other hand, regional governments may have an incentive to push their own citizens onto other regions' health care services since they do not pay for the associated costs, creating a risk of under-provision of health care services at the national level in the longer run. The reluctance of patients to be treated far away and the closer proximity between voters/patients and policy makers may, however, mitigate this effect.

\section{The case for transferring responsibilities to the municipalities is mixed}

21. Spanish municipalities have rather limited responsibilities. Local governments' share in total public spending is smaller than in several unitary OECD countries, largely reflecting their very low involvement in the education and health care sector. Their spending share is, however, very similar to that of federal OECD countries. The devolution of responsibilities to municipalities (Pacto local) is now on the political agenda, in particular because of the willingness to rebalance political forces between the central government and the regions. Economic functions under consideration for decentralisation include limited responsibilities concerning education, housing and employment policies which may have effects which extend beyond municipal boundaries (spillover effects). As discussed above, to be effective employment policies need to be co-ordinated throughout the country; there is a risk that existing problems at the regional level could be exacerbated if core responsibilities were transferred to the local level. It is also telling that in Switzerland, a highly decentralised country, municipal labour offices have recently been replaced by regional placement offices. As far as housing is concerned, decentralisation could result in the under-provision of social housing because municipalities could be reluctant to attract low-income households since they often entail higher costs (e.g. for social welfare programmes). Concerns are less acute for primary education since the central government still controls part of the curricula, thus avoiding large differences across municipalities which could create a barrier to geographic mobility. But the lack of professional expertise to manage schools in very small municipalities still remains an important cause of concern.

22. One serious constraint to the transfer of responsibilities is the high degree of fragmentation. Several empirical studies suggest that there are significant risks of losing the benefits of scale economies below 5000 inhabitants. ${ }^{13}$ Among them, Solé-Ollé and Bosch (2003) estimated that spending needs per head in a municipality with 1000 inhabitants is $23 \%$ higher than in a municipality with 5000 inhabitants. Yet, Spanish municipalities are very small in international comparison with, on average, 5269 inhabitants in 2003 and with $85 \%$ of municipalities having less than 5000 inhabitants (Table 2). While many countries have encouraged the merging of municipalities to exploit scale economies, no mergers have taken place in Spain since the early 1980s. ${ }^{14}$ Some municipalities have even split, raising the number by 86 . Meanwhile, $74 \%$ of the municipalities have entered into co-operative agreements (mancomunidades and consorcios) to jointly provide some services, most frequently waste treatment, water provision and elderly care. Although joint provision may allow scale economies to be exploited, it is not without drawbacks. In France where this approach is common, concerns have been raised that reliance on such subsidiary bodies may lead to a failure of democratic control leaving citizens with little influence over local services because these intergovernmental bodies - with different legal background and territorial coverage - are not elected by the population and are often not very transparent (le Saout, 1998). 
Table 2. The size of municipalities in Spain and several EU countries

\begin{tabular}{|c|c|c|c|c|c|}
\hline \multicolumn{4}{|c|}{$\begin{array}{l}\text { A. Distribution of municipalities by size } \\
\text { in Spain (2003) }\end{array}$} & \multicolumn{2}{|c|}{$\begin{array}{l}\text { B. Average size of a municipality } \\
\text { international comparison (2001) }\end{array}$} \\
\hline $\begin{array}{l}\text { Number of } \\
\text { inhabitants }\end{array}$ & $\begin{array}{c}\text { Number of } \\
\text { municipalities }\end{array}$ & $\%$ of total & $\begin{array}{c}\% \text { of total } \\
\text { population }\end{array}$ & Country & $\begin{array}{l}\text { Number of } \\
\text { inhabitants }\end{array}$ \\
\hline 0-999 & 4921 & 60.7 & 3.6 & Spain $^{2}$ & 5269 \\
\hline $1000-4999$ & 1983 & 24.5 & 10.5 & Belgium & 17400 \\
\hline $5000-9999$ & 531 & 6.5 & 8.5 & France & 1600 \\
\hline $10000-49999$ & 543 & 6.7 & 25.3 & Germany & 5900 \\
\hline $50000-99999$ & 73 & 0.9 & 11.5 & Italy & 7100 \\
\hline 100 000-499999 & 51 & 0.6 & 23.3 & United Kingdom & 135700 \\
\hline$>500000$ & 6 & 0.1 & 17.2 & Sweden & 30800 \\
\hline
\end{tabular}

1. 2003 for Spain.

2. Population data are based on municipality registration numbers.

Source: INE and Dexia Crédit Local.

\section{Financing arrangements for regional governments}

23. Spain recently introduced a new financing arrangement for the common regime regions which is based on several commendable principles (Box 3). First, although País Vasco and Navarra are still governed by a specific system for historical reasons (see below), the new financing arrangement now covers all the 15 common regime regions. The 1997-2001 arrangement had not covered three regions which thus remained under an earlier arrangement. Second, contrasting with previous quinquennial arrangements, the new arrangement is conceived to be permanent. This should reduce uncertainty as well as political and financial negotiation costs. Third, the regions' reliance on locally-raised taxes was increased significantly, reducing the gap between their spending responsibilities and revenue-raising powers. Fourth, equalisation principles underlying the new arrangement are sound and widely accepted. The regions' contribution to the common pool is progressive since the central government retains a share of income and consumption taxes, while financial resources made available to them reflect population needs as measured by objective criteria (i.e. demographic and topographic variables). Fifth, central government transfers have been made independent of the regions' actual economic performance, thus reducing moral hazard problems and the risk of poverty traps. As the implementation of the system has deviated from initially defined principles, several serious issues have emerged, however, which tend to undermine the acceptance of the current arrangement. This section will highlight the most important ones.

\section{The regions are now less dependent on grants and have more revenue-raising powers}

24. The new financing arrangement provides for a significant increase in the financial autonomy of the regions by substituting central government grants for tax resources. In the mid-1990s, regions' own taxes accounted for less than one-quarter of their financial resources and the discretion to set either the tax base or rate was virtually non-existent. ${ }^{15}$ The 1997-2001 arrangement provided the regions with a $15 \%$ share of the personal income tax revenues collected within their boundaries with limited rights to set rates and tax credits. The 2002 arrangement vastly widened both the range of tax bases and the regions' discretionary powers (Table 3). In 2003, own taxes accounted for 53\% of the regions' total revenues and regional governments had the power to set rates or bases for over half of these taxes. In this new set-up, regional governments are now expected to be in a better position to respond to local citizens' preferences in terms of the quality of public services and tax levels. Higher revenue-raising powers at the regional level should also reduce the need for central government assistance were some regions to face financial difficulties (implicit bailouts), thus limiting moral hazard problems. On the other hand, a higher reliance on locally-raised taxes has increased the regions' sensitivity to cyclical shocks. The diversification of regional tax bases, with consumption taxes now accounting for almost two-thirds of their tax revenues (Figure 4), however mitigate the risk of excessive volatility on the revenue side. 


\section{Box 3. Main features of the 2002 financing arrangement for common regime regions}

A new financial arrangement for 15 (out of a total of 17) regions was agreed upon in 2001 and implemented in 2002. It embodies a set of criteria that set the financial resources for the regions and their distribution across them, as well as rules on how these resources, and in particular intergovernmental transfers, will be adjusted over time.

\section{Computing the amount of resources to be made available for regional governments for the base year}

- Regional spending needs in 1999 were set as the sum of revenues (tax proceeds and central government grants) regional governments received collectively in that year (set as the base year) as a result of the financing systems in force until 2001. These included the one corresponding to common responsibilities, the one corresponding to the health care system and the other to social services. Nevertheless, for those regional governments which took over health care responsibilities in 2002 the financing needs were set in bilateral negotiations with the central government (mainly on the basis of historical costs).

- The overall spending needs in the 1999 base year amounted to $€ 54.9$ billion (9.7\% of GDP). The spending needs deriving from the exercise of the common responsibilities amounted to $€ 30.7$ billion, including a general fund to be allocated across regional governments, a fixed amount ( $€ 0.04$ billion) given to each region, and a fund for sparsely populated regions ( $€ 0.05$ billion) and a fund for poor regions ( $€ 0.2$ billion). The general fund was split according to population (94\%), area $(4.2 \%)$, population density $(1.2 \%)$ and island status $(0.6 \%)$. Health care spending needs amounted to $€ 23.4$ billion. The criteria used for allocating the heath care fund were population (75\%), population above age $65(24.5 \%)$ and island status $(0.5 \%)$. Social service spending needs amounted to $€ 0.81$ billion, and their allocation was based on population above age 65. Several adjustments were made afterwards. In particular, no region would lose from the new financing arrangement (garantía de minimo).

- $\quad$ For 2002, the financial resources provided by the arrangement amounted to $€ 67.4$ billion, i.e. 9.7\% of GDP. In fact, regions received more resources, because actual revenue from the taxes they collect was higher than notional tax revenue embodied in the arrangement.

- For each region, transfers from, or contributions to the central government were calculated as the difference between "adjusted" spending needs and its revenue-raising capacity. Two regions (Madrid and Baleares) have revenue-raising capacities exceeding their financing needs and, thus, contribute to the main fiscal equalisation scheme (the Fondo de Suficiencia). All others are net recipients. In 2002, net transfers from the central government via the Fondo de Suficiencia amounted to $€ 22.6$ billion (3.3\% of GDP). This system entails significant differences in the composition of revenues across net recipient regions. As an illustration, central government transfers through the Fondo de Suficiencia accounted for $63 \%$ of Extremadura's financial resources provided by the new arrangement in 2002, compared with $17 \%$ in Cataluña.

\section{Adjusting regional government resources over time}

Equalisation grants to the regions will be adjusted in line with central government's tax revenues, irrespective of each individual region's actual economic performance. To reduce the risk of too strong differences in revenues across regions from emerging, the system specifies maximum and minimum growth rates for overall regional government resources.

Central government equalisation transfers to net recipient regions will be adjusted every year in line with the rise in central government tax revenues. The net contribution of Baleares and Madrid to the equalisation pool will be adjusted to reflect changes in the region's tax revenues (excluding the effect of discretionary changes in regional taxes) or, if lower, national tax revenues. 
Table 3. Regional governments' main tax resources before and after 2002

\begin{tabular}{ll}
\hline \multicolumn{1}{c}{ Before 2002 } & \multicolumn{1}{c}{ Personal income tax 2002} \\
\hline & \multicolumn{1}{c}{ Regional governments are allowed to set tax rates (the } \\
$\begin{array}{l}\text { Regional governments were allowed to set tax rates } \\
\text { and introduce tax credits over 15\% of the personal }\end{array}$ & $+/-20 \%$ limit was removed but regional governments \\
$\begin{array}{ll}\text { income tax base with some limitations. In particular, the } & \text { have to maintain a progressive schedule and the same } \\
\text { rates had to be maintained within a }+/-20 \% \text { range of } & \text { number of brackets as the central government) over } \\
\text { those set by the central government. They received a } & 33 \% \text { of the personal income tax base. They can also } \\
\text { further 15\% of personal income tax revenue collected } & \text { set tax credits and modify central government tax credit } \\
\text { within their jurisdiction but had no discretionary power } & \text { for the acquisition of a residence though with some } \\
\text { over this share. } & \text { limitations. }\end{array}$ \\
\hline
\end{tabular}

\section{Value added tax}

Regional governments had no share and no discretionary power over the VAT.
Regional governments receive $35 \%$ of the revenues collected within their jurisdiction but have no discretionary power to set either the base or the rate.

\section{Wealth tax}

Regional governments received all the revenues and

Same as before 2002 except that restrictions on the were allowed to set the exemption threshold, rates and level and progressivity of tax rates were removed. to introduce specific tax reliefs, though with some limitations.

\section{Inheritance and gift tax}

Regional governments could introduce tax allowances and credits. They could also set rates but with some limitations as regards their level and progressivity.
Same as before except that restrictions on the level and progressivity of rates were abolished.

\section{Tax on wealth transfers and legal acts}

Regional governments received all the revenues and were allowed to set the rates and introduce tax credits, with some limitations.
Same as before 2002 except that limits on the setting of rates were softened.

\section{Tax on gambling}

Regional governments received all the revenues and

Same as before 2002 .

were allowed to set the taxable base and rates.

\section{Excise taxes on tobacco, alcohol and mineral oil}

Regional governments had no share in, and no discretionary power over, excise taxes.
Regional governments receive $40 \%$ of revenues collected within their jurisdiction but have no discretionary powers on the base or rates.

\section{Tax on retail sales of oil products}

This tax did not exist.

Regional governments are allowed to piggyback on the central government excise tax, within certain limits.

\section{Tax on electricity}

Regional governments had no share in, and no discretionary power over this tax.
Regional governments receive $100 \%$ of the revenues collected within their jurisdiction but have no discretion over the base or rates.

\section{Tax on certain means of transport}

Regional governments had no share in, and no discretionary power over this tax.
Regional governments receive $100 \%$ of the revenues and can set the tax rates, with some limitations.

Source: National authorities. 
ECO/WKP(2005)23

Figure 4. Tax revenue by government level

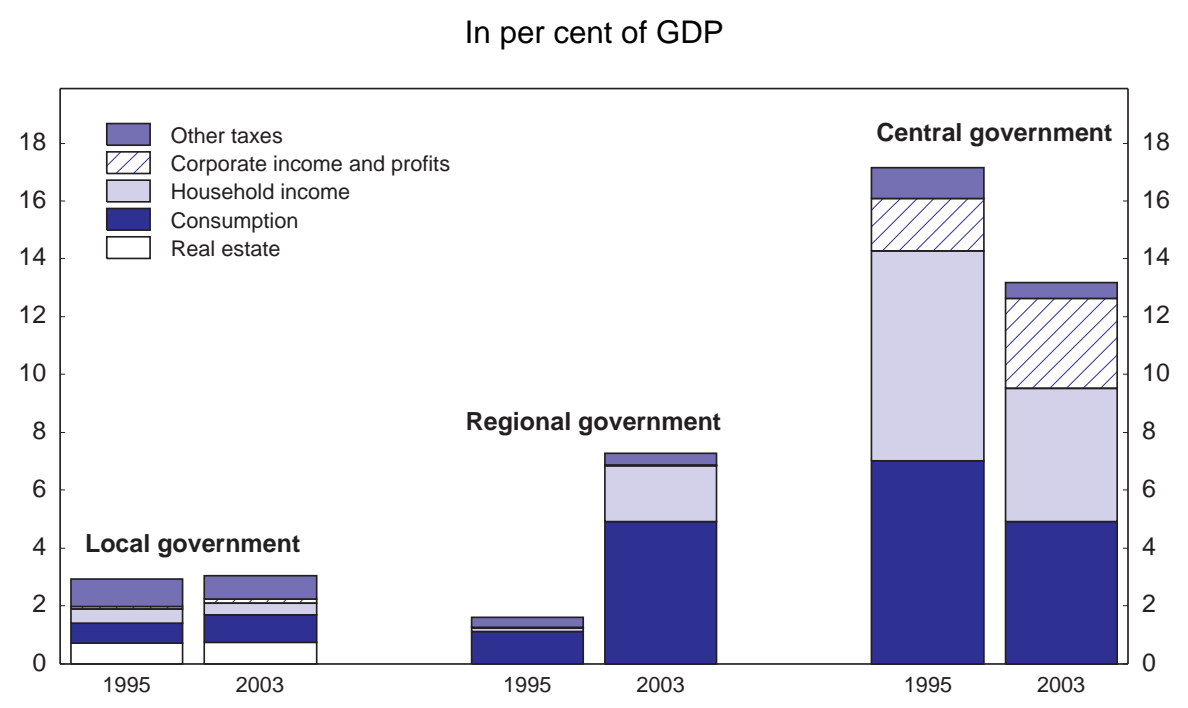

Source: OECD, National Accounts.

25. The greater regional tax autonomy has not been fully exploited, likely reflecting the lack of tax data at the regional level as well as expectations that the financing arrangement will be revised. Regional governments have introduced various tax reliefs on the taxes on wealth and wealth transfers and four of them have introduced a tax on retail sales of oil products. They have, however, only marginally used their discretionary powers for the personal income tax which accounts for the lion's share of the tax revenues over which they have discretion. So far, none has changed statutory rates and, though most of them have introduced or increased deductions associated with family or housing expenses, the revenue impact was tiny in most cases (Table 4). This may partly reflect the difficulties in estimating the potential revenue impact of any changes in marginal rates, since tax data are not fully available to regional governments to perform policy simulations, while the costs of introducing tax credits are much easier to assess. Long delays in publishing data on regional tax collection further reinforce this uncertainty and hinder the use of discretionary powers by the regions. The agreement between the central government and the regions reached in October 2004 has the potential to improve the situation, however. Another reason for the reluctance of the regions to use their tax powers is that the existing arrangement is under rising criticism. Regional governments may prefer to adopt a strategic wait-and-see attitude since any move could weaken their negotiating position should the arrangement be re-negotiated. 
Table 4. The use of regional governments' discretionary powers for personal income tax

\begin{tabular}{|c|c|c|c|c|c|c|c|}
\hline & \multirow{2}{*}{$\begin{array}{l}\text { Change in } \\
\text { rate level or } \\
\text { structure } \\
\text { since } 2002\end{array}$} & \multirow{2}{*}{$\begin{array}{l}\text { Revenue loss } \\
\text { from regional } \\
\text { changes in tax } \\
\text { parameters in } \\
2002^{1}(\%)\end{array}$} & \multicolumn{5}{|c|}{ Special tax credits in 2004} \\
\hline & & & Family & Housing & Employment & $\begin{array}{l}\text { Environment/ } \\
\text { culture }\end{array}$ & Education \\
\hline Andalucía & No & 0.0 & Yes & Yes & Yes & .. & .. \\
\hline Aragón & No & 0.0 & Yes &.. &.. & .. &.. \\
\hline Asturias & No & 0.0 & Yes & Yes & Yes & .. & .. \\
\hline Baleares & No & 0.5 & Yes & Yes &.. & Yes & .. \\
\hline Canarias & No & 0.0 &.. &.. & .. & Yes & Yes \\
\hline Cantabria & No & 0.0 & Yes & .. & .. & .. & .. \\
\hline Castilla-La Mancha & No & 0.7 &.. & .. & .. & .. & .. \\
\hline Castilla y León & No & 0.5 & Yes & .. & .. & Yes & .. \\
\hline Cataluña & No & 0.3 & Yes & Yes & .. &.. & Yes \\
\hline \multicolumn{8}{|l|}{ Comunidad } \\
\hline Valenciana & No & 0.6 & Yes & Yes & .. & Yes & .. \\
\hline Extremadura & No & 3.3 & Yes & .. & Yes & Yes & .. \\
\hline Galicia & No & 0.8 & Yes & Yes & .. & .. &.. \\
\hline Madrid & No & 0.2 & Yes & Yes & .. & Yes &.. \\
\hline Murcia & No & 0.3 & Yes & Yes &.. & Yes &.. \\
\hline La Rioja & No & 0.8 & Yes & Yes &.. &.. &.. \\
\hline
\end{tabular}

1. Measured as the differences between actual and potential revenues (i.e. without any change in the tax parameters at the regional level) over the receipts deriving from the regional part of the personal income tax (33\% of the tax rates).

Source: Ministerio de Hacienda, Medidas normativas aprobadas por la comunidades de regimen comun en materia de tributos cedidos.

\section{There is not enough flexibility to account for demographic developments}

26. Although the new arrangement was conceived to be permanent, it has been increasingly questioned. Demographic variables used to derive the financing needs were those of 1999. Since then, however, immigration has risen rapidly and is concentrated in a few regions. In 2003, $68 \%$ of the foreign residents registered by municipalities (padrón) were living in four regions (Madrid, Comunidad Valenciana, Cataluña and Andalucía). Although the overall fiscal impact of immigrants is likely to be positive, it may not be so for all levels of government. In particular, the rise in social security contributions, accruing to the central government, accounts for most of the revenue gains from migration while the effect of migrants on public spending is concentrated on health care and education services (in particular for non-EU migrants) which are funded by regional governments (OECD, 2003b). ${ }^{16}$ As a result, some regions claim that their financial resources are insufficient to deliver proper education and health care services to which immigrants are entitled as soon as they are registered in the municipal padrón. The arrangement does allow for some adjustment - the so-called asignaciones de nivelación - but only if a region's population grows by more than 3 percentage points above the national average in one year. This condition is very restrictive, because it does not account for the accumulation of deviations over a longer period of time. ${ }^{17}$ This adjustment mechanism is also asymmetric since it only leads to an upward adjustment for those regions with a growing population and no downward adjustment for those with a declining population. In addition, while the arrangement did take account of the age structure in 1999, no adjustment is envisaged afterwards while demographic developments may differ significantly from one region to another. 


\section{Financial arrangements are still subject to criticism}

27. Despite efforts to give prominence to objective needs criteria in designing the new financing arrangement, all regions are not treated equally. To reach an agreement with all regional governments, the central government had to guarantee that no region would lose from its implementation compared to the previous model - the so-called garantía de mínimos. ${ }^{18}$ Since similar guarantees were implemented in previous negotiations, initial misallocations were perpetuated. Likewise, when assessing the financial needs for those regions which had health care responsibilities transferred only in 2002, past actual costs have been accounted for, with some regions receiving significantly more, on a per capita basis, than others. Reaching final agreement with all regional governments also required special bilateral negotiations and adjustments (including convenios and contratos-programas) to the objective criteria, although information on the extra financial resources granted to the regions is not yet available. ${ }^{19}$ Overall, while no region has lost from the implementation of the new arrangement -- the amount of resources made available to them even increased -- deviations from an objective criteria model are spurring demands for more central government financing and/or a higher share in national tax revenues. ${ }^{20}$

28. The specific financing arrangements for País Vasco and Navarra exacerbate demands for more regional tax autonomy in other regions and/or adjustment to the existing financing framework. Per capita incomes in both País Vasco and Navarra are among the highest in Spain. Yet, the Foral system (Box 4) entails that these two regions keep virtually all the taxes collected within their jurisdiction and do not contribute to the pooling of tax revenues at the central level. As a consequence, they do not participate in the regional equalisation system and their financial resources per inhabitant are above those of other rich but common regime regions, leading to claims by the latter that they are unfairly treated. ${ }^{21}$ Extending the Foral system to all regions would, however, reduce the resources flowing from rich to poor regions to a pittance and, thus, entail reconsidering two principles embodied in the Constitution: solidarity across regions and sufficiency in resources to finance the activities transferred to them. On the other hand, because País Vasco and Navarra are two relatively small regions (they accounted for $6.4 \%$ and $1.7 \%$ respectively of Spain's GDP in 2003), extending the new financing system for common regime regions to them would not change drastically the contribution of rich regions to the equalisation pool.

\section{Box 4. Main features of the Foral system for País Vasco and Navarra}

While País Vasco and Navarra's spending responsibilities are broadly similar to those of any other Spanish region, their financing principles differ significantly:

- Revenue-raising powers are much wider than in the 15 common regime regions. País Vasco and Navarra are responsible for setting the tax rates and base, managing and collecting all taxes, except for customs duties and some excise taxes (VAT rates and exemptions are set by the central government but collected by the País Vasco and Navarra administration). They basically retain all tax revenues collected within their jurisdiction, although some arrangements between the central government and País Vasco and Navarra are in force to share some revenues, e.g. for companies operating both in País Vasco or Navarra and in another region or for VAT.

- Intergovernmental transfers flow from País Vasco or Navarra to the central government, contrasting with the situation in other regions which retain only a part of tax revenues collected within their jurisdiction. The so-called cupo, paid by País Vasco and Navarra to the central government, corresponds to the region's payment for a few public services provided by the central government (mainly foreign affairs and defence, as well as debt amortisation). This level of contribution is defined by the ratio of País Vasco and Navarra's GDP to the national GDP. 
29. Rich common regime regions are increasingly claiming that they are penalised by financing arrangements. First, although there are no official price indices which would allow a comparison of price levels across regions, partial evidence suggests that the cost of providing services is higher in the richest regions. In particular, wages, construction and housing costs are higher (Carbó Valverde, 2004). Since the financial resources made available to these regions are based on the number of residents without adjusting for differences in delivery costs, rich regions may not be in a position to provide comparable services to their citizens for the same amount of funding per capita. Adjusting for provision costs may, however, create serious disincentives to control costs, especially since public wages account for a large share of spending on core public services (such as education and health care). Second, the demand for some public services (e.g. health care or tertiary education) tends to increase with the level of income. It would, however, be difficult to justify economically and politically higher transfers for rich regions, especially since they do have significant revenue-raising powers.

30. Aside from the equalisation schemes, the central government provides extra financial support to regional governments on a discretionary basis, though with a clear redistributive bias in a number of cases. The distribution of earmarked grants associated with bilateral agreements between the central government and individual regions as well as the distribution of central government investment across regions provides some evidence. A distributional bias in public investment in favour of low-income regions also exists in other OECD countries, in particular Japan. In Japan and Spain, however, rates of return on public infrastructure in the poorer regions tend to be low (Figure 5). It could thus be argued that it would be preferable to take decisions on the regional allocation of central government public investment purely on efficiency grounds while relying on more efficient instruments for the redistribution of income across regions (such as equalisation schemes) and/or across individuals (the tax and social security systems). ${ }^{22} \mathrm{De}$ la Fuente et al. (2003b) further suggest that increasing educational attainment in low-income regions would be more effective in reducing the productivity gap than infrastructure projects.

\section{Existing financial arrangements may make it difficult to cope with future spending pressures}

31. The sustainability of the current financing model may be undermined over the long run because of ageing-related spending pressures. The two main components of regional governments' resources i.e. tax resources and central government transfers - are likely to grow broadly in line with GDP over the long term, although a slightly faster increase in revenues from consumption taxes in the coming years can be expected. ${ }^{23}$ Pressures on regional governments' spending on health and elderly care are, however, likely to be considerable, partly reflecting population ageing. Available estimates for a number of OECD countries that will experience a milder demographic shock and already have better developed facilities for the care of the elderly suggest that total health expenditure (including long-term care) related to ageing might increase by about $3 \%$ of GDP by 2050 .

32. The financing of this likely increase in regional spending is an important question. Requiring regions to use their revenue-raising powers to cover most of it would likely strengthen incentives to improve cost-efficiency. An increase in regional excise taxes could be envisaged, in particular because overall excise taxes on tobacco and oil products are low in Spain compared with most other EU countries. Still, the regional governments' room for manoeuvre is currently limited and such environmental/health taxes may not be the best sub-national taxes. ${ }^{24}$ Since personal income tax is the main tax that can be changed, this would also imply a significant increase in taxes on labour. Negative consequences on the country's economic performance and on the central government budget - a potential decline in working hours and employment and, thus, reduced social security contributions combined with higher social benefits to be paid should be of concern. ${ }^{25}$ An increase in consumption taxes, which are mostly controlled at the central government level, would likely have a less adverse impact on the economy, but there is the risk that this would undermine the drive for cost-consciousness by the regions. 
Figure 5. Regional distribution of central government investment and earmarked grants ${ }^{1}$

National average $=1$
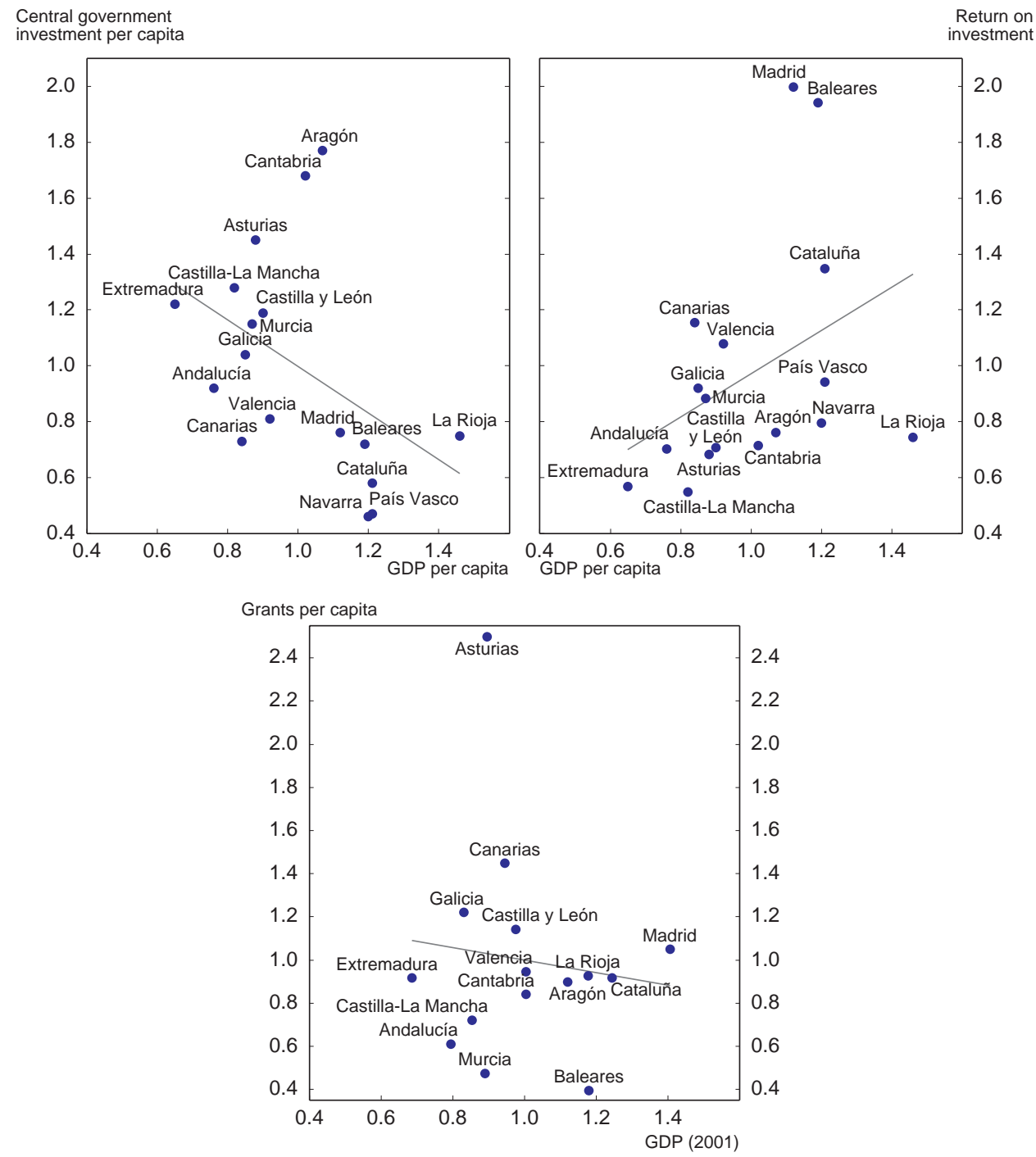

1. Central government investment for 1991-2000 and GDP for 1991-95 are both at constant prices. The return on investment is measured by the marginal rate of return on public investment in 1995, using the calculations of de la Fuente. Data for earmarked grants correspond to central government transfers in the form of specific transfers (subvenciones estatales, convenios and contratos programa) for 2001.

Source: Ministerio de Fomento (2003), "Estudio de la regionalización y provincialización de la inversión pública. Año 2002"; A. de la Fuente (2001), "Infraestructuras y política regional", Centra de Recerca en Económia Internacional (CREI), Cataluña; INE; Ministerio de Economía y Hacienda and information provided by national authorities.

\section{Financing arrangements for local governments}

\section{Local governments' taxing powers are wide,...}

33. Tax revenues accounted for more than half of local governments' non-financial resources in 2002, a high share by international standards (Figure 6). Local governments also have significant discretionary powers, in particular the right to set the rate (within a range defined by the central government) and to introduce specific tax relief for their own five taxes: real estate and local business taxes, the taxes on motor vehicles, construction and public works and on capital gains on land. The 2003 
local government tax reform (Annex A1) exempted individuals carrying out professional activities and companies with a total turnover lower than $€ 1$ million (over $90 \%$ of taxpayers) and compensated municipalities through grants and tax-sharing arrangements. The overall impact on local government taxing powers is, however, mixed and in any case difficult to assess at this early stage since small municipalities have been given wider discretion to set rates and large municipalities now receive a share of VAT revenues, personal income tax and excise taxes collected within their jurisdiction, though with no right to set either the base or the rates.

\section{Figure 6. Local government financial resources in selected OECD countries}

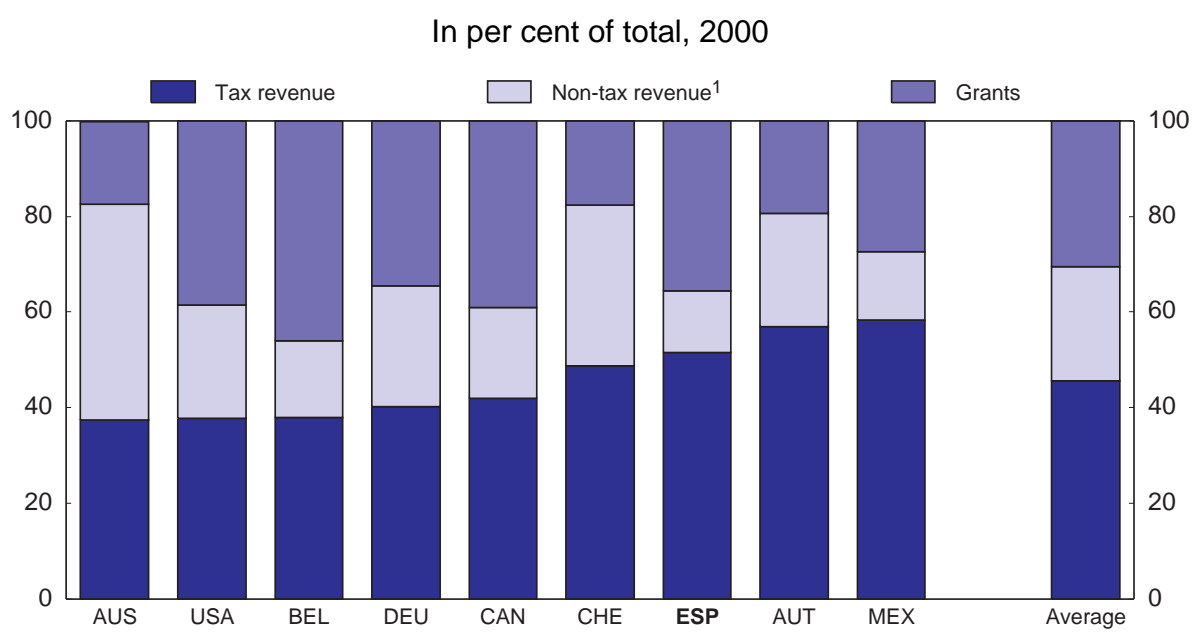

1. Non-tax revenues include: operating surpluses of public entreprises controlled by sub-national governments; property income; fee, sales and fines; contributions to government employee pension funds and capital revenues. Source: IMF (2004), Government Finance Statistics Yearbook, 2003.

\section{... but some local taxes raise equity and efficiency issues}

34. The local business and real estate taxes still raise equity and efficiency concerns which should be addressed. To mitigate the potential perverse impact of a presumptive business tax on company creation, small and recently-created companies were given special treatment. This has not only introduced new distortions and could spur tax avoidance. The introduction of the threshold has raised the complexity, though some simplification has also been made. Firms have incentives to exploit the progressivity of the corporate tax system by breaking up activity into multiple firms to keep their marginal tax rates low, although new rules attempt to avoid this. ${ }^{26}$ The real estate tax also raises important issues. Property values for tax purposes are well below market prices, because they are re-evaluated by the central government only about every decade. In addition, revisions are not carried out simultaneously across the territory and this can create significant horizontal inequities across municipalities, calling into question the legitimacy of this tax base. ${ }^{27}$ Partly as a result, municipalities have tended to introduce tax relief. This is reflected in a much lower ratio between actual and potential revenues for the real estate tax than for any other municipal tax (Poveda Blanco and Sánchez Sánchez, 2002). Overall, proceeds from the real estate tax amounted to $0.7 \%$ of GDP in 2002, a low share in international comparison (Figure 7). 
Figure 7. Recurrent taxes on immovable property in OECD countries

Revenues in per cent of GDP, $2002^{1}$

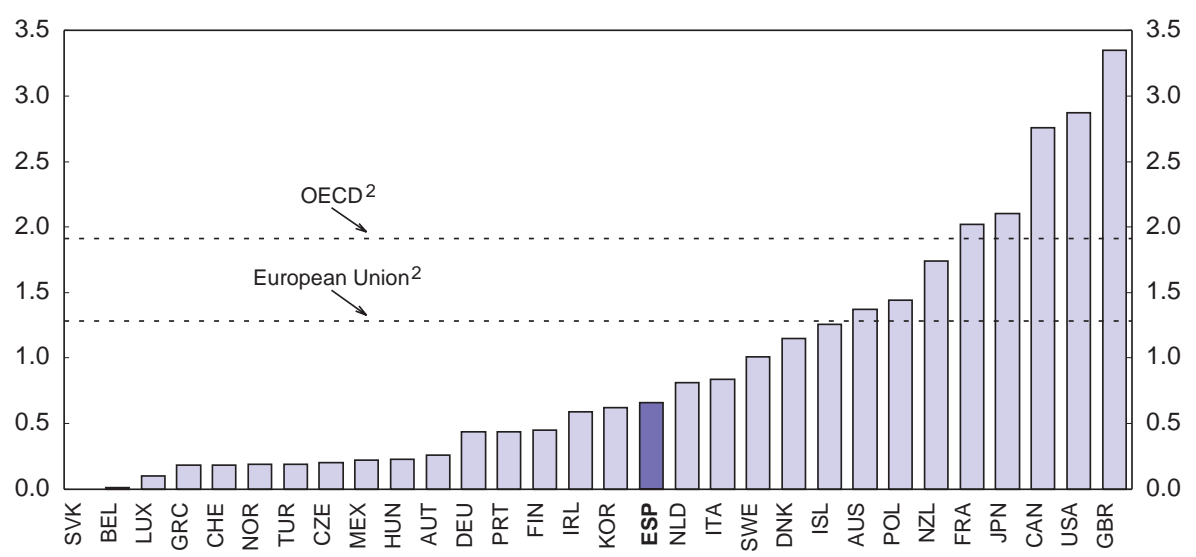

1. 2001 data for Portugal.

2. Weighted average using 2000 GDP and PPPs.

Source: OECD (2004), Revenue Statistics, 1965-2003.

\section{Managing fiscal policy in a decentralised framework}

\section{Decentralisation has been accompanied by fiscal consolidation}

35. Spain's budgetary situation has been relatively good since the early 2000 s, even though important pension reforms are necessary to maintain this situation in the long run (OECD 2005, chapter 5). The regional and local authorities' debt has been low and slightly decreasing as a proportion of GDP, while that of central government is falling rapidly (Figure 8). This performance is considerably better than the euro area average and has been achieved within the context of increasing decentralisation. It is the result of a strategy in place since 1992, the thrust of which is twofold: on the one hand, close co-ordination between the fiscal consolidation policies of all levels of government so as to comply with commitments under the Maastricht Treaty and the Stability and Growth Pact and, on the other, the application of central government administrative controls on territorial authorities' borrowing.

36. The need to implement such a strategy became apparent with the worsening of the public accounts in the late 1980s and early 1990s, which mainly affected the budgets of the regions, whereas the economic situation was still favourable (Figure 9). This fiscal slippage seems to have been partly due to strategic behaviour, the regions underlining their growing resource needs in the context of the decentralisation process then under way (García-Milà et al., 2001). It could not be prevented by the then existing mechanisms to guarantee the financial health of the territorial authorities. These mechanisms mainly involved limiting the authorities' borrowing. ${ }^{28}$ To ensure Spain's participation in monetary union, the authorities established in 1992 a system for co-ordinating the fiscal policies of the different authorities. Medium-term consolidation scenarios were drawn up so as to be consistent with the convergence plans for the country as a whole. The central authorities and regions, meeting in the framework of the Council for Fiscal and Financial Policy (CPFF), thus decided on the breakdown by level of government of the maximum deficit and debt consistent with national objectives. They did this on an individual basis for the regions and central government and on a global basis for the local authorities. These limits supplemented the administrative borrowing restrictions over which the CPFF also established closer control. ${ }^{29}$ Being based on a broad consensus, this fiscal policy co-ordination seems to have been essential in ensuring fiscal consolidation (Salinas Jiménez and Álvarez Garcia, 2002). In fact, the application of these plans brought a reduction in debt and deficit levels as of the mid-1990s, even if targets were overshot in some regions and, generally speaking, finances were less well controlled in the large towns than in the small municipalities (Monasterio-Escudero and Suárez-Pandiello, 2002). 
Figure 8. Public debt by level of government

In per cent of GDP ${ }^{1}$
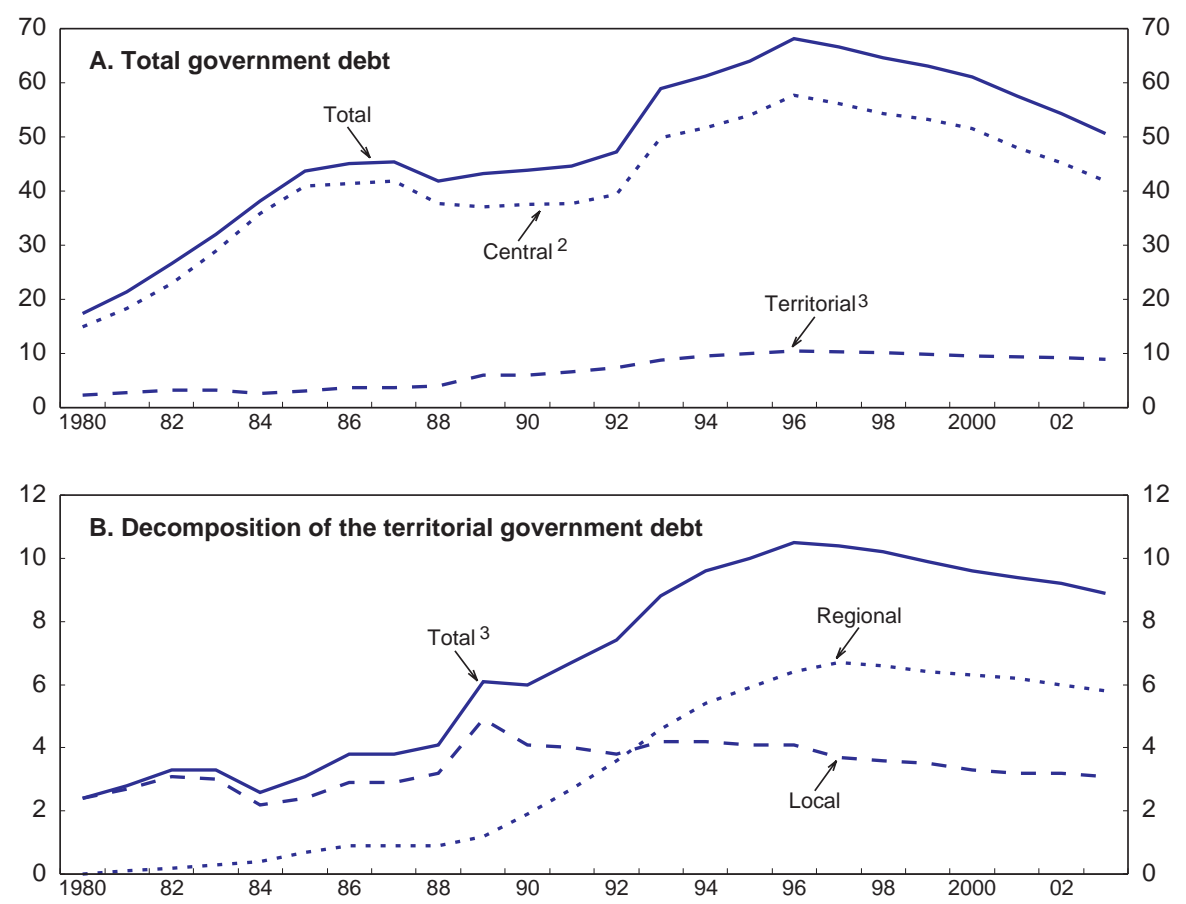

1. On the basis of ESA 79 (European system of accounts 1979) before 1995.

2. Including social security.

3. Territorial government is composed of the regions and municipalities.

Source: Bank of Spain.

Figure 9. Government financial balances

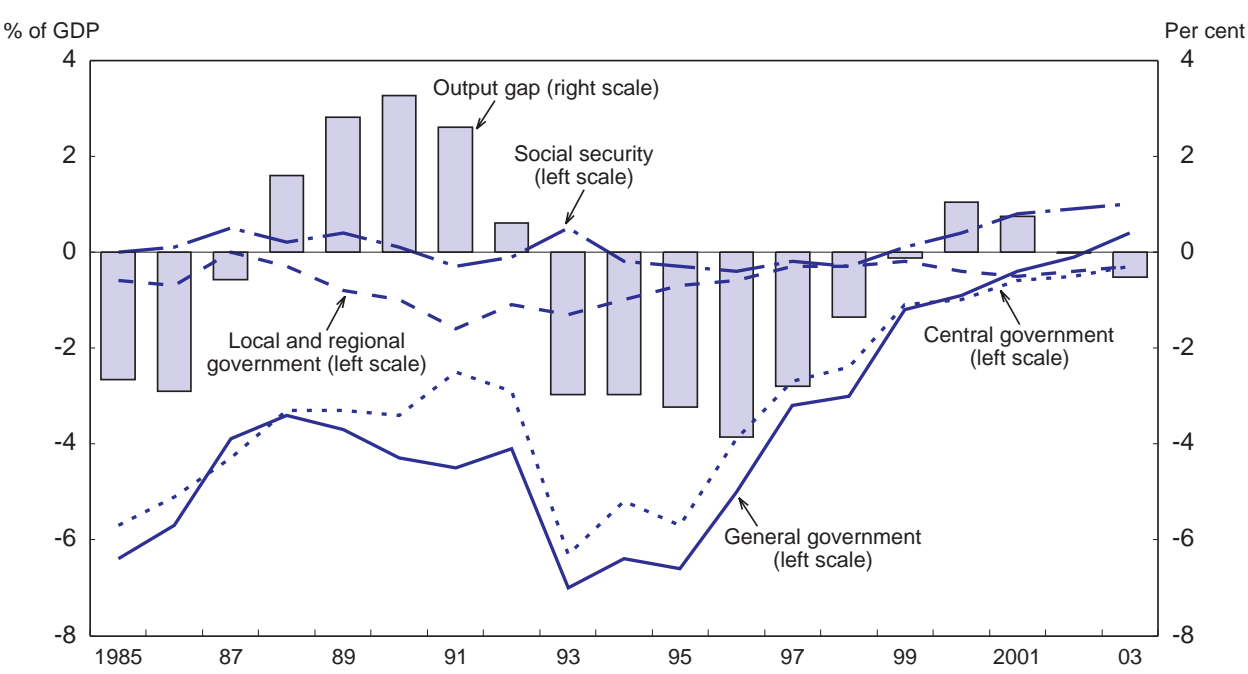

Source: Ministerio de Economía y Hacienda. 
ECO/WKP(2005)23

\section{The new Fiscal Stability Law is designed to preserve fiscal discipline}

37. The desire to perpetuate the benefits of fiscal consolidation prompted the authorities to amend the co-ordination system by adopting the Fiscal Stability Law (FSL). It was applied for the first time in 2003 and established a uniform rule requiring that accounts at all levels of government be kept permanently in balance or in surplus (Box 5). The FSL tightened the restrictions on indebtedness requiring that indebtedness stabilises or falls, except for the purchase of financial assets since such operations do not affect the deficit, or when there are temporary occurrences of a deficit as stipulated by the law. In such cases, the territorial authorities are obliged to obtain central government authorisation for credit transactions, which first of all requires the approval of a consolidation plan.

\section{Box 5. The Fiscal Stability Law and the recent discussions to reform it}

The objective of the Fiscal Stability Law (FSL) is to maintain fiscal discipline at all levels of government by keeping the public accounts permanently in balance or in surplus. ${ }^{1}$

This rule is incorporated in a multi-annual framework (the stability programme) to be consistent with the targets set at the beginning of each year and approved by Parliament. Its application is overseen by the Council for Fiscal and Financial Policy (CPFF), which consists of the central government Finance and Public Administration ministries and the representatives of the communities. The law does not rule out deficits. However, that possibility is confined to temporary and exceptional situations and has to be properly justified. In the event of a deficit, a four-year action plan to improve the situation has to be submitted within 20 days and has also to be ratified by the CPFF, even if this deficit is of a cyclical nature.

The FSL does not provide for any disciplinary action if the regions do not comply, unless failure to do so causes the Maastricht Treaty's 3\% deficit ceiling for government as a whole to be exceeded and thus results in Spain eventually having to pay a penalty. Compliance with fiscal discipline is nevertheless ensured by the supervision and mutual surveillance exercised by the central government and the regions within the CPFF. Also, if the fiscal stability targets are not met, borrowing by the Communities to ensure their financing has to have central government approval. The same authorisation is required for bond issues or loans in foreign currency.

In June 2005, the government presented to the Senate broad guidelines for reforming the FSL in the context of the debate on the Stability Programme for the period 2006-08 and on the spending ceiling for the central government for 2006. The main changes considered in the Press Communiqué were as follows:

- The state and sub-national governments would be allowed to post deficits during cyclical troughs but would be required to produce surpluses when activity is buoyant. Deficit would be allowed only when GDP growth falls below $2 \%$. For these administrations, however, the deficit should not be higher than $1 \%$ of GDP at any time, with the following repartition: $0.75 \%$ of GDP for the regions, $0.20 \%$ for the state and $0.05 \%$ for the municipalities. The social security will not be covered by the rule;

- The reformed FSL would allow an additional deficit for the general government of up to $0.5 \%$ of GDP to finance approved multi-annual programmes of investment, with the following repartition: $0.25 \%$ of GDP for the regions, $0.20 \%$ for the state and $0.05 \%$ for the municipalities;

- $\quad$ Once the annual overall fiscal target has been set and broken down between the state and the sub-national governments, individual fiscal targets for regional governments will be set through bilateral agreements.

- Administrations not complying with the rule and recording a sizeable deficit will be required to present a plan, which will be published, aiming at restoring their financial equilibrium. Restrictions on indebtedness will also be tightened.

1. This rule also applies to public companies. During a transition period which is scheduled to end in 2012 , the balance constraint imposed by the FSL applies to the consolidated sector of the State and social security.

38. During its first year in operation, the FSL fulfilled its role of keeping the public accounts in balance, even if the local and regional authorities did record small deficits - respectively of $0.1 \%$ and $0.2 \%$ of GDP in 2003. Although the balance or surplus target was not met in 11 out of 17 regions, most of the deficits were reduced. Only two Communities, Comunidad Valenciana and Cataluña, which account for over 95\% of the total regional deficit (Figure 10), were required to submit a plan to restore financial equilibrium by 2008 . 
Figure 10. Regional debt and deficits
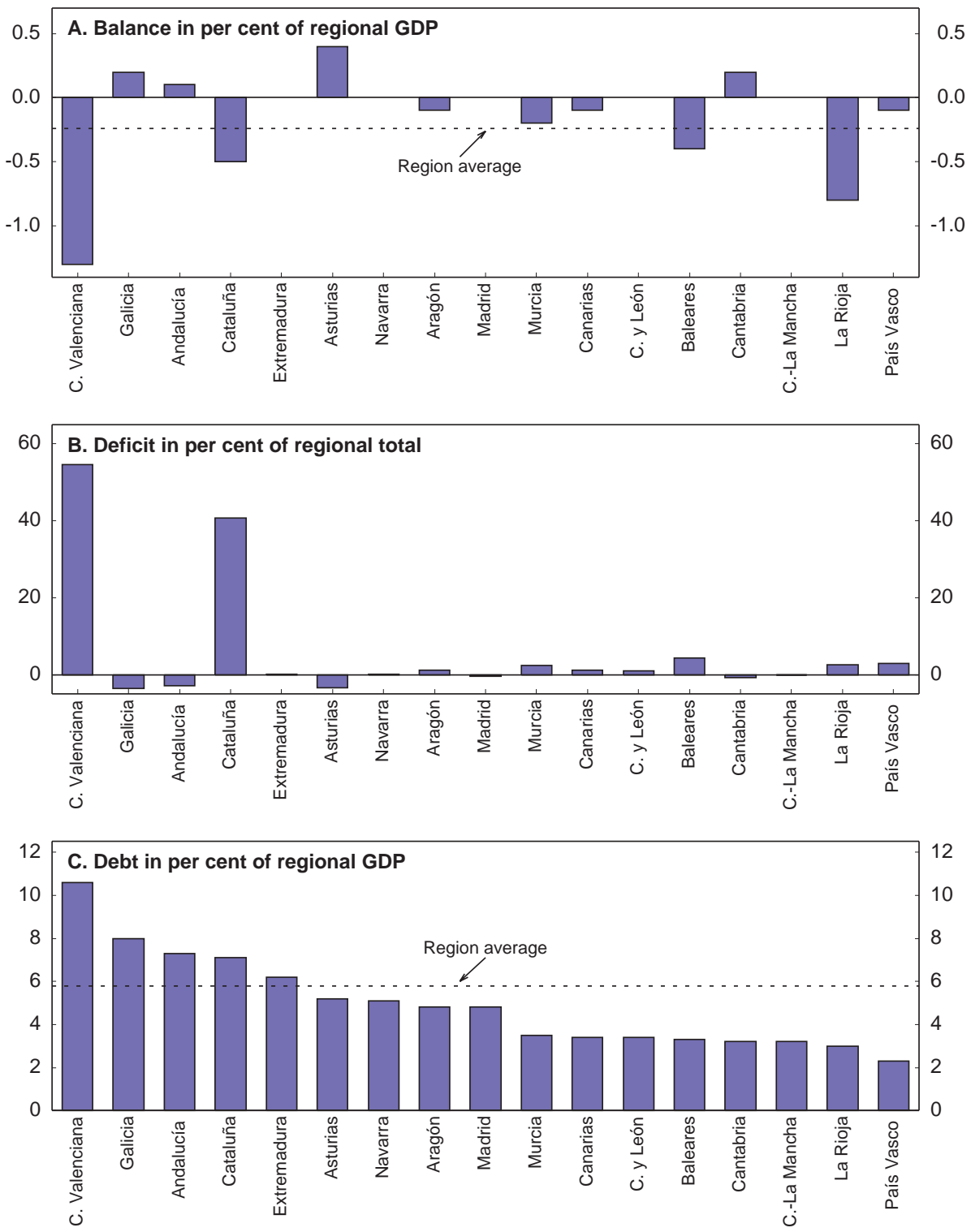

Source: Intervención General de la Administración del Estado (IGAE) and Bank of Spain.

\section{Recourse to a fiscal rule is appropriate...}

39. Recourse to a fiscal rule, such as the FSL, shows the authorities' concern that all levels of government play an active role in maintaining sound public finances. In contrast with the situation in a number of federal OECD countries, the autonomous communities have not formulated their own fiscal rules for guaranteeing the financial viability of their public finances. The fact that central government has introduced a fiscal rule aimed at filling the vacuum seems preferable to a strategy relying solely on the financial markets to ensure fiscal discipline. Although the markets do make some distinction between the risk premiums on borrowing by the different regions, the differentials remain limited. ${ }^{30}$ This is no doubt due in part to the low level of regional debt, but it may also reflect that administrative authorisation is 
required in order to borrow - a system which could well be seen as a tacit central government guarantee with respect to regional borrowing. It would probably be difficult to resist political pressure for a rescue plan in favour of an authority in serious financial difficulty. In the early 1980s, for example, there were financial rescue plans for municipalities (Monasterio-Escudero and Suárez-Pandiello, 2002). ${ }^{31}$ Failure by central government to intervene in such circumstances could result in disruption in the provision of public services, equal access to which is guaranteed by the Constitution.

\section{... but the FSL's excessive rigidity could have a destabilising macroeconomic effect...}

40. Another advantage of a fiscal rule is to reconcile fiscal discipline and co-ordination between the different levels of government. From that point of view, however, the FSL poses problems which the authorities have recognised. While it has the advantage of being both simple and easy to convey, the rule is nevertheless formulated in a rigid way. It does not allow for the effects of the economic situation on the public accounts, which could result in fiscal policy playing a destabilising pro-cyclical role. This is a problem that affects central government and the social security most, their revenue being closely linked to the economic situation. ${ }^{32}$ However, it also affects the regions and large towns following the recent reform of the way they are financed, which has made their resources more sensitive to cyclical fluctuations, while the inertia of regional spending has been accentuated by the transfer of responsibility for health care. Having too rigid a framework makes it more difficult for the territorial authorities to manage investment programmes. Empirical work shows that capital expenditure was one of the main adjustment variables during periods of sluggish activity (Esteller-Moré et al., 2004) (Figure 11). ${ }^{33}$ The application of the FSL could accentuate this feature, which is not desirable either for reasons of macroeconomic stabilisation or for reasons of effective project management.

Figure 11. Government investment and the economic cycle ${ }^{1}$

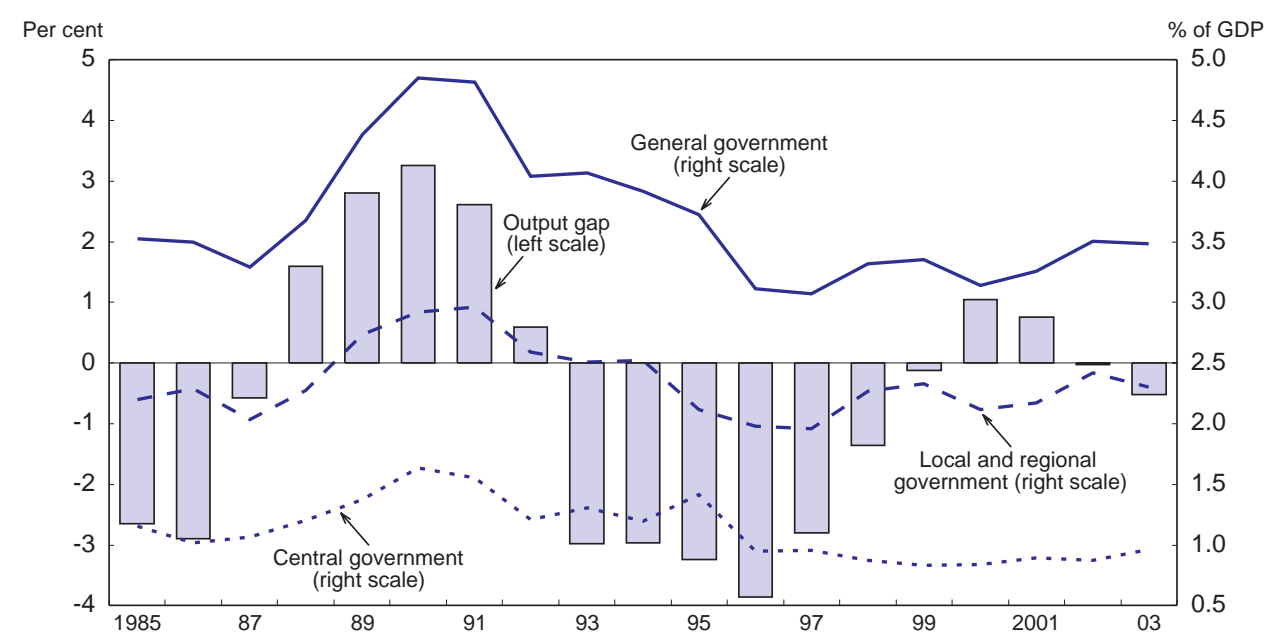

1. Break in series in 1995 for investment.

Source: INE and Bank of Spain. 


\section{... and to foster the growth of off-budget operations detrimental to transparency}

41. If the rule is seen as being too coercive, there is a risk that it will encourage the development of off-budget operations, which raises transparency problems and could call the rule's credibility into question. The authorities' only way to increase their borrowing to finance investment currently involves the acquisition of financial assets via capital transfers to public companies which are not covered in the general government accounts (Amor and Pou, 2004). However, such operations, which use the experience of the business sector in managing certain types of infrastructure and introduce greater competition in the provision of certain services, also appear to be driven by the desire to escape the borrowing constraints. This is suggested by the recent sharp increase in the debt of public companies controlled by the regions, a phenomenon which is also apparent - though to a lesser degree - in the case of the local authorities (Figure 12). What is more, the risks surrounding future trends in the deficit and the debt attaching to these transfers or to the various forms of partnerships with the private sector are not always systematically identified and quantified and this information is not contained in the budget documentation. ${ }^{34}$ Such problems were identified for central government and led to an upward revision of spending in the 2004 budget (OECD 2005, Chapter 2), but they also apply in much the same way to the sub-national governments, which nowadays account for two-thirds of total public investment. ${ }^{35}$

Figure 12. Debt share of public enterprises

In per cent of their respective government debt

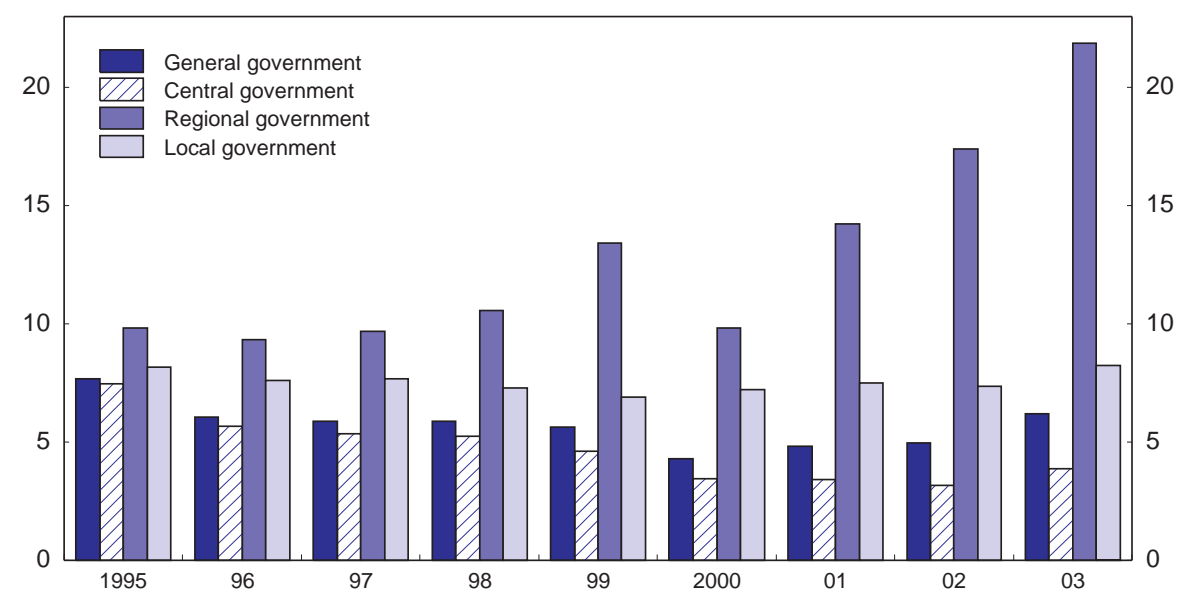

Source: Bank of Spain.

\section{Greater transparency of the public accounts is needed}

42. The new government has announced its intention to remedy the FSL's shortcomings and dealing, first of all, with the problems concerning the transparency of public sector activity as a whole. This will be done by improving the documentation of the central government budget so as to ensure for instance a better assessment of the future risks involved by investment programmes. ${ }^{36}$ Changes to the FSL have also been proposed to raise transparency, which are especially pertinent in the case of the regions whose accounts are available late and only in fragmented form. ${ }^{37}$

\section{The fiscal rule should be made more flexible...}

43. The government plans to increase the flexibility of the FSL by accounting for the cyclical conditions when setting fiscal targets for the general government. However, applying this principle, which seems a legitimate way of preventing fiscal policy from destabilising the economy, raises various practical 
questions. The first of these concerns the level of government to which the new principle should apply. At present, the FSL requires that the accounts of all levels of government taken individually be kept in balance. Using a fiscal balance norm throughout the entire cycle is, however, not a feasible option authority by authority, including at local level, nor is it even necessarily desirable. Indeed, local authorities' revenues are not very responsive to cyclical fluctuations. ${ }^{38}$ In the case of the social security, maintaining structural surpluses seems preferable to applying a fiscal balance rule, both for reasons of macroeconomic stabilisation and to strengthen the public finances to cope with ageing.

\section{... but this will require a pragmatic and transparent approach...}

44. Balancing budgets over the cycle would seem desirable in the case of central government and the regions taken as a whole ${ }^{39}$ for example by calculating structural balance indicators. Still, applying a structural fiscal balance rule to individual regions would raise practical problems. This is because the regions, especially the smallest ones, can be affected by specific shocks which may make their cyclical position asymmetric to that of the rest of the economy, and this is liable to affect their revenues (Figure 13). Small regions' budgets can also quickly move into deficit because of large investment projects, as was the case in La Rioja in 2003 following the construction of a hospital. To overcome this difficulty, the authorities could consider applying a mechanism for sharing deficit and debt targets which would be set globally for all the regions, in much the same way as the co-ordination system worked between 1992 and 2002. This arrangement, which was based on a consensus as to the general objectives and a system of implicit sanctions linked to the borrowing constraint imposed by central government, appears to have been effective. To solve a similar problem, Austria experimented with a mechanism for trading deficit rights between territorial authorities, but the effectiveness of this system is not yet established. $^{40}$

45. A second challenge is to avoid a weakening of the norm as a result of its increased complexity. If the new rule were insufficiently transparent, there could be opportunities for manipulation which would undermine its credibility; however, that risk could be limited by establishing clear mechanisms for assessing the cyclical position of the economy. A mechanical method of producing statistical estimates of the output gap could be used to guarantee the transparency of the calculation, ${ }^{41}$ but a probably better solution would be to ask a group of experts, or an independent institution such as the central bank, to provide an estimate of the output gap by means of a detailed analysis. The effect of the business cycle on government accounts has also to be taken into account in a transparent manner by providing information on the tax revenue elasticities with respect to economic activity. In any case, it should be recognized that structural balances are difficult to estimate and need to be cross-checked using alternative approaches. ${ }^{42}$

\section{... which needs to balance the specific regional requirements and those of the whole country}

46. The debate about the flexibility of the fiscal rule at the regional level prompts questions as to the limits that should be set in this connection. In some respects, even if the effect of the business cycle were taken into account, a uniform fiscal balance rule could seem unnecessarily restrictive, bearing in mind the regions' differing requirements stemming from their sizeable disparities in development. It might in that case seem preferable to resort to a golden rule and leave the regional governments more room to invest and borrow so as to build the infrastructure essential to their development. However, such an approach would to some extent call into question the co-ordination of fiscal policies. Also, making a distinction which attaches more importance to physical capital than to current spending looks debatable considering, for example, how effective a well-managed education system is as a way of bolstering human capital and economic growth. 
Figure 13. Regional gap differences from the country average ${ }^{1}$ Per cent
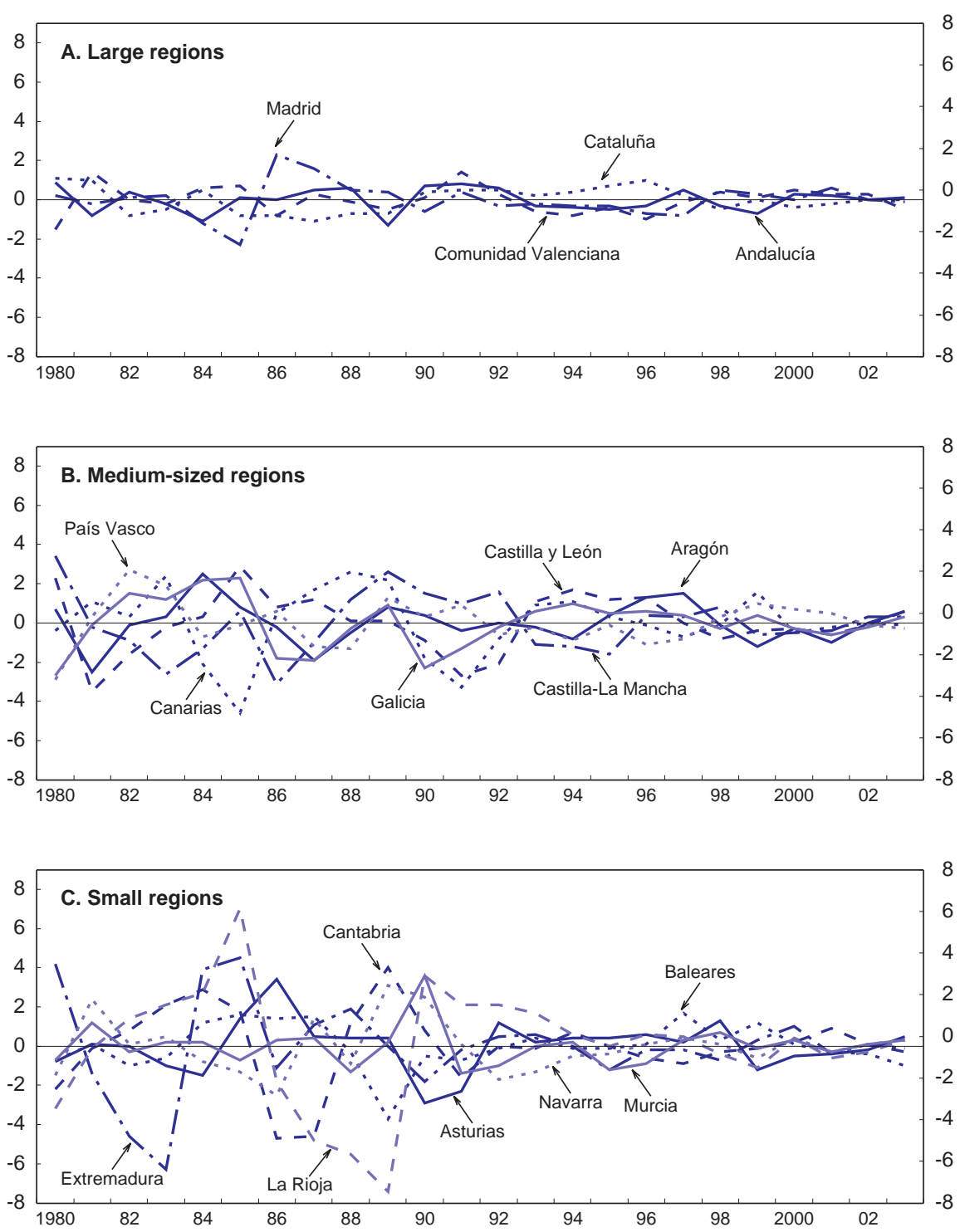

1. Trend output is calculated via a Hodrick-Prescott filter.

Source: Eurostat.

47. Another point of view, however, holds that it is important not to underestimate the risks attaching to a fiscal rule which relates solely to budget balances and can therefore result in a steep and simultaneous rise in expenditure and taxation, even though up to now the sub-national authorities have apparently been reluctant to increase their taxes. This phenomenon was observed in Denmark, Finland and Sweden, where the territorial authorities have considerable independence with respect to direct taxation - as in Spain - but do not take account of the negative externalities that an increase in their tax pressure generates. ${ }^{43}$ Risks of this sort would justify introducing an expenditure-capping mechanism, whereas at present the regions are free to decide whether to raise taxes or lower outlays to balance their accounts. Such constraints might be thought excessive in the case of Spain however; tax pressure is still relatively low and education and infrastructure are still lagging behind a little, while upward pressure on health spending will persist. 


\section{An agenda for further reform}

48. The rapid devolution of spending and revenue-raising responsibilities to the regions has not compromised fiscal consolidation. The current assignment of spending and tax responsibilities across levels of government and the intergovernmental transfer system provide opportunities to better meet local preferences and promote innovative policy approaches while maintaining policy consistency at the national level. However, reaping the full benefits of this decentralised framework would require the implementation of a number of reforms (Box 6 provides a synopsis). These reforms would contribute, in particular, to: avoiding the duplication of resources and containing the upward drift in public spending; promoting high quality public services; ensuring that the overall tax system does not create large distortions; and securing fiscal discipline while avoiding a pro-cyclical fiscal stance or an increase in off-budget operations.

\section{Box 6. Recommendations for improving fiscal relations across levels of government Develop information systems on sub-national government policies and performance}

- Promote the sharing of experience across sub-national governments.

- Develop benchmarking for services provided by sub-national governments and make the results public (for instance, waiting lists for hospital care) so as to enable local citizens to exert pressure on regional governments to improve the cost-effectiveness of their actions.

- Facilitate sub-national governments' access to tax data on a timely basis so as to enable them to introduce better informed tax policies.

- Improve the transparency of sub-national government budgets and audit them by an independent body to avoid the expansion of off-budget operations through public enterprises.

\section{Reform the rules governing public employment}

- Increase the flexibility of permanent job contracts in the public sector and of wage setting to better reflect local circumstances.

\section{Upgrade the financing framework for the regions}

- Take demographic developments better into account by softening the conditions for implementing the asignaciones de nivelación when regions have experienced changes in total population since 1999. Population changes should be taken into account in a symmetric way. Announce well in advance how financing arrangements for the regions will respond to the likely increase in regional government spending stemming from population ageing.

- Gradually correct existing deviations from the objective needs criteria when adjusting the regions' financial resources for developments not fully accounted for in the framework (in particular demographic developments and the fiscal consequences of ageing).

- Relax the obligation for regional governments to spend a minimum amount on health care. Make the health cohesion fund more supportive of regional co-operative arrangements: the financial compensation received by providing regions should cover the full costs and be paid by the region of origin.

- Avoid using earmarked grants or at a minimum increase transparency on the overall amount and criteria used to allocate them across regions. Reconsider undue regulations imposed on regional governments using earmarked grants, in particular for ALMPs.

- Reduce the bias in favour of less developed regions in allotting central government investment. Consider using more effective instruments in supporting poor regions' growth potential (such as education policies) and/or in redistributing income.

\section{Reform local government taxes and be prudent in transferring new spending responsibilities}

- Consider carefully the potential risks (losses of the benefit of scale economies and adverse spillover effects) which would result from the transfer of new responsibilities to the local sector before taking a decision.

- Increase local governments' reliance on the real estate tax. To this end, the land register should be upgraded so as to provide more homogeneous and up-to-date property tax values.

- Abolish the local business tax.

\section{Enhance the flexibility of the fiscal rules}

- Amend the Budget Stability Law so as to account for the impact of cyclical developments on the central government and aggregate regional budgets.

- Rely on the Council for Fiscal and Financial Policies to set fiscal targets for individual regions on the basis of individual medium-term scenarios. Regions overshooting their targets because of a significant structural deficit should still be required to present a medium-term adjustment plan. 


\section{Develop information systems on sub-national government policies and performance}

49. Consistent and timely information on policies implemented at the sub-national level and on their outcomes should be made widely available so as to promote the diffusion of best practice, facilitate co-ordination and promote competitive pressure and fiscal discipline. To play such a role, the collection and publication of the relevant information should be independent from the government to raise acceptance and credibility.

50. A more systematic sharing of bad and successful experiments is desirable. In the past, conferences organised by the central government ministries have had a limited success in this regard, partly because regional governments' decision to attend has often reflected political affiliation. The October 2004 meeting of regional and central governments, mostly devoted to the discussion of health care financing, is a notable exception in this regard. Efforts to improve co-ordination across and between levels of government should be further promoted and should be complemented by a greater use of benchmarking so as to better identify best practice. Benchmarking would also have the advantage of enhancing competitive pressures on sub-national governments - pressures which are less well developed in Spain than in several other OECD countries (in particular Switzerland and the United States) where citizens "vote with their feet" (geographic mobility is higher than in Spain) and/or voice their preferences through an extensive use of local referenda on policy matters.

51. Benchmarking would require defining and publicising indicators, consistent for the whole territory, on regional and local public services so as to enable citizens to press their government to improve cost-effectiveness. In Spain, the new government is committed to improve the quality of information on public services, in particular with the creation of the National Quality Agency. The previous government also passed a Law on University Reform which created a new national agency to evaluate teaching and research activities of university departments and the Health and Consumption Ministry set up an agency for health quality in August 2003. However, the lack of resources for these new agencies and the new government's decision not to publish regional data for health care waiting lists seriously limit the potential benefits of these agencies' work. Proper evaluation of regional ALMPs should also be implemented so as to ensure that they fully support the government's objective of promoting employability. The Swiss system provides a valuable experiment, where benchmarking of regional labour offices has helped to identify best practice. Introducing financial incentives for the regions to improve the quality of ALMPs or transferring to them the financial responsibility for unemployment benefits could raise difficult political and equity concerns and should thus only be envisaged if the naming and shaming of the weakest performers did not suffice to lift average performance.

52. Better information systems would facilitate the achievement of national objectives, the formulation of regional policies and the co-ordination across sub-national governments. The recent implementation of an integrated system for job demands and offers (SISPE) in all regions should facilitate adjustment in regional labour markets. It would also be useful for the central government when designing the National Vocational Training and Insertion Plan and for regional governments to implement it. A regular assessment of this new information system should be performed so as to ensure that it responds adequately to the evolving needs of both the regional and central authorities. Likewise in other sectors (in particular health and elderly care), existing facilities could be used more effectively, needs could be better identified and duplication could be avoided if better information were available. Regional governments should also be given sufficient access to tax data in a timely fashion not only to carry out policy simulations and implement better informed tax policies but also to fight tax avoidance. To this end, improved co-operation between the national tax administration and regional governments should be given priority over decentralisation of the tax administration, since it would both reduce information segmentation and contain tax collection costs. 
53. Greater transparency of sub-national government accounts is also vital in view of the substantial increase in off-budget operations in recent years. It would also give some impetus to the complementary role played by financial markets in keeping the public finances in a sound condition by differentiating more between the borrowing conditions on the basis of their financial performance. There should be greater transparency in book-keeping between government and public enterprises, particularly in the framework of public-private partnerships. The expansion of such operations would probably be slowed by the removal of the present constraint prohibiting borrowing other than for the purpose of purchasing financial assets. Transparency should be assessed by an independent body so as to avoid credibility problems stemming from partisan approaches and make it easier to check the accounts of the regions. Lastly, efforts need to be made to reduce the long delays in publishing the detailed final accounts of all levels of government and to ensure the publication of quarterly accounts reflecting general government budget outturns on a consolidated basis consistent with the national accounts.

\section{Reform the rules governing public employment}

54. Reforming the rules governing public employment would contribute to avoiding the duplication of resources and to better adapting to changing needs for public services. To put an end to the upward drift in public employment, less reliance on life-long job contracts should be considered and barriers to mobility within the public sector scrapped, in line with recent developments in a number of OECD countries. Subnational governments should be given more leeway in designing the work contracts of their employees and in setting wage levels so as to reflect local conditions better.

\section{Upgrade the financing framework for the regions}

55. The main principles underlying the new financing arrangement for the regions are sound but some adjustments are needed to make them sustainable in the face of demographic developments, in particular recent migration inflows as well as population ageing. In the absence of such adjustments, three risks could materialise: $i$ ) some regions will no longer be in a position to deliver the minimum national standards for core public services; ii) regions will increase regional taxes, resulting in a tax mix which is sub-optimal for the country as a whole and thus impinging on its growth performance; and iii) the regions expect revisions to the model, do not raise taxes but rely on debt with the expectation to be bailed out by the central government. To avoid these risks, the central government should account for recent demographic developments, and in particular changes in population reflecting large migration flows into some regions, in adjusting central government transfers to, or from, the regions over time. This should be done by changing the Asignaciones de nivelación which are currently too strict and asymmetric - regions with a growth in population compared to 1999 should receive more central government transfers while those with a declining population should receive less.

56. Although ageing has had little budgetary effect so far, its future effect should be recognised and accompanying changes in the regional financing arrangement should be announced well in advance so as to avoid putting its credibility at risk. Efficiency gains in the public sector may serve to finance part of the likely increase in regional spending on health and long-term care over the medium term. However, some increase in taxes seems difficult to avoid if spending for these items were to grow as much as projected. In this context, an important objective of the central government should be to contain the potential negative impact of a tax hike for the economy as a whole, while creating the right incentives at the regional level to control spending. An increase in excise and value-added taxes, which are relatively low, would likely be better than an increase in personal income tax (mainly falling on labour), which is the main tax regional governments can change. In distributing the proceeds from higher consumption tax rates across regional governments, two approaches could be implemented to keep regional governments cost conscious. The first one would be to assess ex-ante the amount of extra spending regional governments would have to finance and distribute this amount across them on the basis of a set of objective criteria, as opposed to 
actual spending, so as to avoid moral hazard problems. This approach could well be implemented within the new financing arrangement for the regions by recognising future spending needs, and thus increased central government transfers, and by giving more weight to the old-age population in the current objective criteria distribution system. In the second approach, extra financing needs could be assessed ex-post, e.g. on the basis of the actual increase in the three "best-performing" regions. Under both scenarios, regional governments would have to finance any deviation from the benchmark or the ex-ante agreement from their own budget. While adjusting financial resources so as to account for the fiscal consequences of ageing or for recent demographic developments, care should also be taken to reduce existing regional disparities in financial resources, in particular those resulting from past recognition of historical costs or from the implementation of the garantía de mínimos.

57. The design of several intergovernmental transfers and support programmes should be reviewed so as to promote cost-effectiveness before increasing the overall amount of financial resources for the regions. First, the obligation to spend a minimum amount on health care should be abolished since it reduces incentives to introduce cost-saving measures. Second, the health care Cohesion Fund should be reformed so as to encourage regional co-operation for hospital care services. To avoid duplication, or alternatively a too low supply of facilities, the financial compensation received by providing regions should reflect the full costs of treating non-residents and should be paid by the region of origin instead of the central government. Giving regional governments a choice between building their own facilities or buying services from other providers would, however, require redressing existing disparities in financial resources across regional governments. Third, the use of bilateral arrangements between the central government and individual regions associated with earmarked grants should be transparent and their distribution across regions based on objective criteria so as to avoid moral hazard and recurrent claims for more central government funds. Fourth, conditions imposed on regional governments using earmarked grants should be reconsidered, in particular for ALMPs (e.g. those regarding unit costs of training programmes and the prohibition of the regions from topping up central government money with their own resources). Fifth, the criteria for distributing central government investment across regions should be reviewed, giving more emphasis to those projects which support productivity gains most and leaving redistributive objectives to other more effective instruments (pure fiscal equalisation schemes or tax and welfare systems).

\section{Reform local government taxes and be prudent in transferring new spending responsibilities}

58. Based on economic considerations, the case for transferring new spending responsibilities to local governments is weak, but their financing could be improved. In the absence of a reform that will lead to the merger of small municipalities, the local supply of core public services will likely suffer from producing at a smaller scale and raise difficult spillover issues (e.g. how to ensure that local decisions on housing, education or employment policies are consistent with national objectives?). On the basis of current spending assignments, their revenue-raising capacity is sufficient. The local business tax (IAE), however, raises equity and efficiency issues. By abolishing the tax for the most affected companies, the 2003 reform has eliminated some problems while creating other distortions. From this perspective, it would be desirable to reconsider the IAE. Increasing the real estate tax which is low by international standards could offset the loss in revenues, while maintaining sufficient revenue-raising powers to respond to local citizens' preferences by adjusting rates over a wider tax base. Reform would probably need to be gradual since people are often particularly sensitive to changes in the real estate tax. It would also require more up-to-date, and thus fairer, property values for tax purposes. New Zealand's approach in this domain could be an attractive model. The national property database was devolved to local governments in 1999 . Councils are now responsible for assessing property values for tax purposes at least every third year and can outsource this task to Valuation Service Providers. Rules setting out valuation requirements are under the responsibility of the central government, whose main objective is to ensure a nationally consistent, impartial, independent and equitable valuation system. 


\section{Enhance the flexibility of the fiscal rules}

59. In recent years, fiscal discipline has been ensured at all levels of government. Recourse to a budgetary rule seems appropriate as it reconciles budgetary discipline and co-ordination between the different levels of government. However, the FSL has since 2003 required that the accounts of all levels of government taken individually be kept permanently in balance. This seems too rigid as it could lead to a pro-cyclical fiscal policy. The rule should be made more flexible to maintain a balanced budget over the cycle, even though some caution is warranted given the uncertainties concerning the cyclical adjustment of budget balances. Some pragmatism will be needed, but this approach would appear possible for central government and the regions as a whole. The authorities would be able to record deficits during cyclical troughs, but these would have to be offset by surpluses during periods of buoyant activity. For local authorities, on the other hand, there does not appear to be a need for change. The specific breakdown of the overall target between the different regions could be managed within the CPFF, as was the case between 1992 and 2002. This collective surveillance system, based on medium-term scenarios for each region and monitoring of borrowing by the central government, seems to have been effective. This mechanism would strike the right balance between the specific requirements of the regions and those of the country as a whole. This would avoid having recourse to penalties, which are difficult to implement, as international experience shows. The regions should nevertheless continue to be obliged to present a medium-term fiscal adjustment plan if they appreciably overshoot their targets, which would clearly indicate a structural imbalance in their accounts. It would, however, be important to ensure that this new norm is imposed evenhandedly on all the regions, whatever their size. It is also important to ensure that complying with a budget balance rule does not prompt a sharp rise in regional and local taxes, which has been an issue in some OECD countries.

60. The guidelines for reforming the Fiscal Stability Law (FSL) made public in June 2005 may serve to address the main drawback of the current FSL, namely the risk of a pro-cyclical fiscal stance. Most notably, the guidelines propose a pragmatic and simple approach to account for cyclical developments when setting fiscal targets. Still, some difficulties may arise should these guidelines be implemented. First, the overall fiscal target may not be ambitious enough since the proposed guidelines allow for a deficit, over the cycle, to finance investment. The deficit ceiling imposed on the regions also appears less ambitious than the one applied to the state. Second, giving a preferential treatment for infrastructure spending could create an undue bias against other spending items that may have a higher social rate of return, most notably education. This special treatment given to spending on infrastructure could further spur the use of accounting tricks. Third, although the growth rate of the economy should be accounted for when setting annual fiscal targets, the size of the gap may not be given sufficient consideration. Yet evidence in OECD countries suggests that fiscal outcomes depend at least as much on accumulated deviations from the potential growth path of the economy than on the annual growth rate. In addition, the $2 \%$ threshold for growth under which a deficit will be allowed seems somewhat arbitrary and not very binding in the medium-term perspective, given the expected weakening of potential output growth resulting from the ageing process. Furthermore, the new rule does not embody any specific mechanism imposing a surplus when the economy grows at a rate above potential. Fourth, individual fiscal targets for the regions would, according to the guidelines, be set through bilateral negotiations, as opposed to a collective surveillance system. This feature, if implemented, would harm transparency and reduce the role of peer pressure in enhancing fiscal discipline. 


\section{NOTES}

1. This paper was originally produced for the 2005 OECD Economic Survey of Spain, which was published in April 2005 under the authority of the Economic and Development Review Committee. The authors would like to acknowledge Pablo Antolin, Andrew Dean, Jorgen Elmeskov, David Grubb, Christopher Heady, Peter Hoeller and Vincenzo Spiezia for valuable comments on earlier drafts or for sharing their knowledge. The authors are also grateful to Isabelle Duong and Desney Erb for statistical assistance and to Sylvie Ricordeau for secretarial assistance. The paper has benefited from discussions with numerous Spanish experts in ministries and regional governments responsible for policy making in this area.

2. In December 2004, the País Vasco Parliament approved a proposal calling for a quasi-independent status for País Vasco, based on the idea of a "free association" of separate nations, with the right to secede fully from Spain at a later stage. Discussions on this issue between the central and regional governments have started. The central government and the main political parties strongly oppose this project, which might lead to a serious institutional clash.

3. The Catalan conservative party (CiU) played a pivotal role in Spanish politics between 1993 and 2000 when it held the balance of power in parliament. The Popular Party won an absolute majority in the 2000 general election. In the 2004 general elections, the Socialist Party did not win an absolute majority and depends on the support of regional parties. The Catalan Republican Left (ERC) has emerged as a significant force in regional politics and has become the fourth-biggest party. The upper chamber (the Senate), which has powers of amendment, has 208 directly elected members, with a further 51 designated by the regions. The government envisages a reform of the senate, which requires changing the Constitution, so as to give more power to the regions by transforming the Senate into a chamber representing the regions and/or by giving the regions the power to veto laws when they could affect their autonomy. The wisdom of going in this direction is open to question, at least on economic efficiency grounds. In Germany for instance the complicated mediation process between the Bundestag and the Länder chamber of Parliament (Bundesrat) has slowed and diluted the structural reform process. The OECD 2004 Economic Survey of Germany recommended to consider limiting the power of the Bundesrat to block federal legislation.

4. Reducing income dispersion across regions will also require improving framework conditions, and in particular labour mobility, which are shaped to some extent by the assignment of spending and revenueraising responsibilities across government levels. In particular, a well-functioning job-matching system and education policies, consistent active and passive labour market policies are all important ingredients. For further discussion on the forces shaping convergence across regions, see the special chapter "Regions at work" in the 2004 OECD Economic Survey of the euro area.

5. The 2003 OECD Economic Survey of Spain contains an in-depth chapter on the economic impact of migration.

6. The labour force survey (EPA) likely overestimates general government employment. As a share of total employment, it rose from $10 \%$ in 1980 to $15 \%$ in 2003 , i.e. a level close to the OECD average. Crosschecking with national accounts data for the wage bill of the general government, however, reveals an apparent inconsistency with the data from the Registro (with surprisingly large movements in wages per capita and a high growth in public wages compared to the private sector).

7. Under the 2004 norm, local and regional governments are not allowed to create permanent positions on a net basis. Up to 2004, all levels of government could replace only one in four retiring civil servants. 
8. See the study Estudio comparative del salario del médico en España (SIMEG, 2004).

9. In Andalucía, Castilla-La Mancha and Extremadura, doctors are required to prescribe on the basis of active ingredients and patients are reimbursed on the basis of the least expensive pharmaceutical containing them. Cataluña has introduced an approach to hospital financing that provides incentives for efficiency and has been a leader in contracting out integrated management of services to private companies (Conference Board of Canada, 2004). Madrid and Comunidad Valenciana have defined maximum waiting times for specific specialised treatments and, once reached, patients are given free access to private health care centres. A system to control prescriptions of anti-inflammatory drugs developed in Andalucía has recently been extended to the whole of Spain. In the long-term care sector, there are also significant regional differences in approaches and services provided (Comas-Herrera et al., 2003).

10. A consumer association (Organización de Consumidores y Usarios, OCU) has carried out valuable exercises to compare the price and quality of services across the country (including elderly and hospital care) but also recognises the difficulty of obtaining reliable information.

11. Responsibility for managing training programmes for the employed was transferred to Cataluña in 1992, Comunidad Valenciana, Galicia and Andalucía in 1993, and to all remaining regions by 1999. Responsibility for training programmes for the unemployed and for placement services was transferred later and completed in the early 2000s (Alujas Ruiz, 2004).

12. In Canada, the federal government maintains total control of the unemployment insurance benefits, but social assistance programmes fall nearly entirely under the control of provincial governments; the funding and the administrative responsibility for a portion of ALMPs were transferred from the federal government to most of the provinces in 1997 (Gray, 2003). On invalidity policies in Spain, see OECD (2003a).

13. These estimates should be considered with caution, since larger municipalities tend to offer more services, resulting in higher average spending per capita.

14. Recently, the Danish government announced a merger reform which is expected to reduce the number of municipalities from 271 to around 100 although the average size of a municipality is already about 20000 inhabitants. This reform is expected to deliver some efficiency gains but most certainly a higher quality of public services.

15. Taxes on wealth and property transactions were until 1997 the main tax resources of regional governments and their base and rates were set by the central government.

16. The net fiscal costs of immigration can also be high for a few medium-sized municipalities which receive a large number of illegal immigrants. They often have to provide food and urgent care to illegal immigrants arriving in poor health condition. The government has, however, announced the creation of a special fund for the most affected municipalities.

17. As an illustration, using the main population variable (población protegida) when assessing the need of adjustment (asignaciones de nivelación), the population of Madrid region grew by $8.1 \%$ over the period 1999-2002, compared with a $4.3 \%$ national average.

18. According to Montero et al. (2004), extra-costs associated with this guarantee would amount to $€ 844$ million, i.e. about $2 \%$ of the total regional financing needs.

19. For 2001, earmarked grants associated with bilateral agreements between the central government and individual regions (subvenciones, convenios and contratos programas) amounted to $€ 3.7$ billion, i.e. over $0.6 \%$ of GDP.

20. According to the Ministry of Finance, the implementation of the new model resulted in a $€ 1.8$ billion increase in financial resources for regional governments for the base year (i.e. $0.3 \%$ of GDP), discounting 
the effect of the changes in spending assignments but excluding other specific transfers which may have been granted to reach an agreement (e.g. convenios and contratos programas). Montero et al. (2004) provide estimates of some of the negotiation costs (increase in transfers) incurred by the central government in reaching an agreement with the regions.

21. The exception is the contribution of Foral regions to the Fondo de Compensacion Interterritorial, which finances infrastructure development projects in poor regions (i.e. those meeting the Objective 1 criteria for European Structural Funds). The overall amount of this fund is, however, small (less than $€ 1$ billion in 2003, i.e. $0.1 \%$ of GDP).

22. For an in-depth discussion of these issues, see de la Fuente (2002), de la Fuente et al. (2003a) as well as Garcia-Milà and McGuire (1996). Alvarez Pinilla et al. (2003) also estimated rates of return on public infrastructure across Spanish regions. While recognising that estimates vary significantly along with the model used to compute rates of return, this work also shows that the rate of return is higher in richer regions.

23. The elasticity of consumption taxes with respect to spending has been above unity since the early 1990s (Bouthevillain et al., 2001). One reason is the changing composition of the consumption basket from goods which are taxed at a reduced VAT rate towards semi-durable and luxury goods which are taxed at the standard rate.

24. Regional governments can introduce a tax on retail sales of oil products up to 1 cent per litre. Granting more discretionary powers on environmental taxes to regional governments, however, raises two main issues. First, tax competition could be intense and benefit small and central jurisdictions (the case of Luxembourg with low VAT and excise taxes on oil products and a very high share of non-residents' consumption). Second, a conflict in objectives may arise since environmental taxes should primarily serve to reduce pollution.

25. Rough calculations provide some illustration. Personal income tax revenues of the regions amounted to $€ 14.5$ billion in 2002 , i.e. $2.1 \%$ of GDP. Were the regional governments responsible for financing only two thirds of the likely increase in health and long-term care spending over the next decades, a doubling of personal income tax revenues would be required. Ceteris paribus, this would entail at least a doubling of regional statutory rates. The top marginal tax rate $(45 \%$ in 2003 when combining the central and regional government rates) would thus increase by over 16 percentage points.

26. Goolsbee (2004) provides such evidence for the United States.

27. To mitigate this bias, the tax law allows municipalities to adjust the tax base (i.e. property values as estimated by the register-Catastro) for the nine years following the revaluation.

28. Up until 2003, the regions' borrowing capacity was limited by capping the total debt service burden (interest plus capital) at $25 \%$ of current revenue. In addition, total local government debt could not exceed $110 \%$ of current revenue and the authorities had to show positive saving to be able to borrow. If these conditions were not met, the territorial authorities had to obtain Ministry of Finance approval. The increase in current revenue prompted by decentralisation and the fall in interest rates resulted in the relaxation of the borrowing constraint on the part of the regions which had no debt when they came into being in the late 1970s.

29. Up until 1992 the mechanisms for overseeing the borrowing rules, which in particular meant that borrowing could only be used to finance investment, were found wanting (Salinas Jiménez and Álvarez García, 2002).

30. According to Alcade Fradejas and Vallés Giménez (2002), certain differences between risk premiums based on the regions' degree of indebtedness existed between 1990 and 1995. However, they were small. Recently, the rating differential between regions has been between AA- and AAt. 
31. In addition, the periodic renegotation of the regions' financing models in the past also seems often to have provided an opportunity to help certain Communities faced with budgetary difficulties.

32. The higher weight taken by corporate tax revenues in total central government resources after the 2002 regional financing reform has no doubt reinforced the sensitivity of the central government revenues to the cyclical fluctuations of the economy.

33. Between 1985 and 2003, the correlation between the output gap and the investment ratio of the regional and local authorities was stronger (0.62) than for central government (0.32). Similar empirical results have been found in other European countries such as Denmark (Borge et al., 2001). See also MonasterioEscudero and Suárez-Pandiello (2002) for the case of Spain.

34. Since the mid-1990s, investment by public/private partnerships has amounted to $6 \%$ of GDP. Such partnerships have in many cases been set up at regional level (IMF, 2004).

35. Eurostat reported recently, for example, that consideration was being given to reinstating in the deficit of the Community of Madrid the transfers it had made to Mintra, the public company responsible for building the capital's underground railway system.

36. Clarification of the links between the public accounts presented on a budgetary basis and those drawn up using national accounts criteria is planned, bearing in mind the difficulties recently encountered in this area concerning both the central and also regional government, as in Cataluña.

37. The most recent detailed information available for all individual regions relates to 2001 and it is difficult to obtain long time series of individual regional accounts on a national accounts basis.

38. In view of the share of their revenues in GDP, which is $6 \%$, a $1 \%$ decline in the output gap results in a cyclical budget deficit by the local government of less than $0.1 \%$ of GDP.

39. The slight fiscal overrun in 2003, which many regional governments attributed to a problem with the financing of health spending, was no doubt also partly due to the cyclical downturn. As a rough guide, a $1 \%$ rise of the output gap leads to a change in the cyclical fiscal balance by $0.1 \%$ to $0.2 \%$ of GDP for the regions as a whole.

40. The experience of Austria in this domain does not appear yet very conclusive. It is likely that finding a proper compensation for the acquisition of a deficit right by a region may require some sort of political agreement with another region, which may not be very transparent. Also, developing a system of trading deficit rights could be more difficult in Spain because of the wide differences in size between the regions.

41. In Switzerland, the output gap used in the budget procedure is calculated by the Hodrick-Prescott filter.

42. For instance, it would be useful to ensure that the increase in public expenditure does not differ much from the trend growth rate of the economy in case where, initially, the budget is in structural equilibrium and no tax change is scheduled.

43. An increase in direct taxation prompted by the territorial authorities reduces the incentives to work, to save and to grow. It also reduces the social insurance contributions and taxes received by central government and can result in higher spending on welfare. 


\section{ANNEX A1. RECENT REFORMS OF THE LOCAL GOVERNMENT FINANCING SYSTEM}

1. The local government financing system was reformed in two steps, with some changes in local taxes in 2003 and a reformulation of central government grants in 2004.

2. The 2003 reform made the local tax system more friendly towards small companies, employment, the environment and families. It also removed the specific limits on small municipalities' taxing powers by allowing them to set the rates within the same range as large municipalities. The main changes in local taxes are as follows:

- The local business tax (IAE): $i$ ) small businesses (turnover less than $€ 1$ million) - i.e. over $90 \%$ of taxpayers - are now exempt, while higher and progressive rates are imposed on larger ones; ${ }^{1}$ ii) the number of employees no longer forms part of the tax base and municipalities are given the opportunity to grant special tax relief to job-creating companies; iii) newly-created companies are exempt for a 2-year period and pay only half of their tax liabilities for the next five years; iv) small municipalities can now vary the tax rates within a wider band, similar to that implemented for large municipalities.

- Tax on immovable assets (IBI): $i$ ) municipalities can now differentiate rates according to the use of the property (commercial, industrial or residential); $i$ ) they have more discretion to introduce tax relief for families with more than three children or for households using renewable energy sources. All municipalities now can set the tax rate within a range of $0.4 \%$ to $1.1 \%$ (small municipalities previously had to set rates within a narrower band).

- Small municipalities have been given the same powers as large ones to set rates for the tax on motor vehicles, the tax on the increase in land prices and the tax on construction and public works.

- Central government transfers to municipalities were reformed in 2004 and an asymmetric system has been introduced: Large municipalities (over 75000 inhabitants) receive a share of the personal income tax (1.7\%), VAT (1.8\%) and excise taxes $(2.1 \%)$ collected within their jurisdiction. These revenues substitute part of the unconditional grant. Small municipalities still receive transfers from the central government based on their needs (population and ability to pay) as well as their tax effort. The differentiation in weight given to the population index has, however, been adjusted to better reflect differences in obligations for service provision according to a municipality's size. A special regime was also introduced for municipalities classed as tourist centres. These will also be assigned a share of the fuel and tobacco excise tax collected within their boundaries (2.0\%) to compensate for the specific costs associated with large inflows of tourists.

\section{NOTE}

1. The abolition of the local business tax for small companies reduced IAE revenues by $€ 900$ million, i.e. by more than half (Sánchez Soliño, 2003). Taking into account the increase in rates on large companies, the net losses for municipalities would amount to $€ 630$ million. Since the tax paid is deductible from the personal or corporate income tax bases, the overall loss for public administrations would be lower - about $€ 410$ million. On the other hand, tax liabilities of large companies have increased and are deductible from central government taxes, so that the net effect is difficult to evaluate. 


\section{BIBLIOGRAPHY}

Alcalde Fradejas, N. and J. Vallés Giménez (2002), "El mercado financiero y el racionamiento del endeudamiento autonómico", Instituto de Estudios Fiscales, Papeles de trabajo, No. 4/02.

Alujas Ruiz, J.A. (2004), "La transformación del servicio público de empleo en España", Cuadernos de Información Económica, July/August, No. 181, Fundación de las Cajas de Ahorros Confederadas, Madrid, www.funcas.ceca.es/Publicaciones/Cuadernos Financiera.asp.

Alvarez Pinilla, A., L. Orea Sánchez and J. Fernández Álvarez (2003), "La productividad de las infraestructuras en España", Papeles de Economía Española, No. 95, Fundación de las Cajas de Ahorros Confederadas, Madrid, www.funcas.ceca.es/Publicaciones/Papeles_Economia_Espanola.asp.

Amor, J.M. and V. Pou (2004), “Comunidades autónomas ante la estabilidad presupuestaria”, Cuadernos de Información Económica, March/April, No. 179, Fundación de las Cajas de Ahorros Confederadas, Madrid, www.funcas.ceca.es/Publicaciones/Cuadernos Financiera.asp.

de Ayala Cañón, L., R. Martinez Lopez and J. Ruiz-Huerta (2001), "La descentralizacion territorial de las prestaciones asistenciales: efectos sobre la igualdad", Papeles de Trabajo, Instituto de Estudios Fiscales, No. 16/01.

Borge, L-E., M. Dahlberg and P. Tovmo (2001), “The Intertemporal Spending Behavior of Local Governments: A Comparative Analysis of the Scandinavian Countries", Department of Economics, Uppsala University, February, www.nek.uu.se/pdf/2001wp10.pdf.

Bouthevillain, C. et al. (2001), "Cyclically Adjusted Budget Balances: An Alternative Approach”, Working Paper Series, No. 77, European Central Bank, September, www.ecb.int/pub/pdf/scpwps/ecbwp077.pdf.

Carbó Valverde, S. (2004), "Endeudamiento y financiación de la vivienda en las regiones españolas", Cuadernos de Información Económica, March-April, No. 179, Fundación de las Cajas de Ahorros Confederadas, Madrid, www.funcas.ceca.es/Publicaciones/Cuadernos_Financiera.asp.

CES (Consejo Económico y Social) (2000), "La movilidad geográfica", Colección informes, 1/2000, Madrid, February, www.ces.es/informes/2000/inf0100.pdf.

CES (2004), "La temporalidad en el empleo en el sector público", Madrid, December, www.ces.es/informes/2004/inf0304.pdf.

Comas-Herrera, A. et al. (2003), "European Study of Long-Term Care Expenditure: Long-Term Care Expenditure in an Ageing Society", Report to the European Commission, Employment and Social Affairs, PSSRU Discussion Paper, No. 1840, LSE Health and Social Care, London School of Economics, February, http://europa.eu.int/comm/employment social/social situation/docs/european study long term car e en.pdf.

Conference Board of Canada (2004), Challenging Health Care System Sustainability: Understanding Health System Performance of Leading Countries, Ottawa, July, www.health.gov.ab.ca/resources/publications/pdf/conference board2.pdf. 
Dafflon, B. and J. Ruegg (2002), “Innovation institutionnelle et logique de 'bas-en-haut': la loi sur les agglomérations du canton de Fribourg (Suisse)", paper presented at the 38th Colloque de l'ASRDLF, held at Trois-Rivières, 21-23 August, www.uqtr.ca/screg/T_RueggDafflon.pdf.

Esteller-Moré, A., A. Solé-Ollé and P. Sorribas-Navarro (2004), "Fiscal Adjustment to Exogenous Shocks: Evidence from Spanish Municipalities", Centro de Investigación en Federalismo Fiscal y Economía Regional, Instituto de Economía de Barcelona, www.revecap.com/veea/autores/E/122.pdf.

European Observatory on Health Care Systems (2000), Health Care Systems in Transition: Spain, Brussels, www.euro.who.int/document/e70504.pdf.

de la Fuente, A. (2002), "Is the Allocation of Public Capital across the Spanish Regions too Redistributive?", Documentos de Trabajo, D-2002-03, Ministerio de Economía y Hacienda, May, www.igae.minhac.es/Internet/Cln Principal/ClnInformacionGeneral/ClnDocumentosTrabajo/Docu mentos.htm.

de la Fuente, A. (2003), "The Effect of Structural Fund Spending on the Spanish Regions: An Assessment of the 1994-99 Objective 1 CSF", Documentos de Trabajo, D-2003-02, Ministerio de Economía y Hacienda, www.igae.minhac.es/Internet/Cln Principal/ClnInformacionGeneral/ClnDocumentosTrabajo/Docu mentos.htm.

de la Fuente Moreno, A., X. Vives Torrent and R. Carminal Echeverría (2003a), "Políticas públicas y equilibrio territorial en el Estado Autonómico", Fundación BBVA, Bilbao, June.

de la Fuente, A., R. Domenech and J.F. Jimeno (2003b), "Human Capital as a Factor of Growth and Employment at the Regional Level. The Case of Spain", Working Papers, No. 610-04, Instituto d'Análisis Económico, Universitat Autònoma de Barcelona, http://pareto.uab.es/wp/2004/61004.pdf.

Garcia-Milà, T. and T.J. McGuire (1996), "Do Interregional Transfers Improve the Economic Performance of Poor Regions? The Case of Spain", Economics Working Papers, No. 207, Department of Economics and Business, Universitat Pompeu Fabra, December, http://netec.mcc.ac.uk/WoPEc/data/Papers/upfupfgen207.html.

Garcia-Milà, T., T.J. Goodspeed and T.J. McGuire (2001), "Fiscal Decentralization Policies and SubNational Government Debt in Evolving Federations", Economics Working Papers, No. 549, Department of Economics and Business, Universitat Pompeu Fabra, July, http://netec.mcc.ac.uk/WoPEc/data/Papers/upfupfgen549.html.

Goolsbee, A. (2004), "The Impact of the Corporate Income Tax: Evidence from State Organizational Form Data", Journal of Public Economics, Vol. 88, No. 11, Elsevier, September.

Gray, D. (2003), "National versus Regional Financing and Management of Unemployment and Related Benefits: The Case of Canada", OECD Social, Employment and Migration Working Papers, No. 14, OECD, Paris, www.oecd.org/dataoecd/13/37/16586079.pdf.

Hernández de Cos, P. (2002), “The New Framework for the Spanish Regional (Autonomous) Governments", Economic Bulletin, Bank of Spain, July, www.bde.es/informes/be/boleco/2002/be0207e.pdf.

IMF (International Monetary Fund) (2004), "Spain: Draft Report on the Observance of the Standards and Codes (ROSC) Fiscal Transparency Module", preliminary draft, IMF, Washington DC, June.

Joumard I. and C. Giorno (2002), "Enhancing the effectiveness of public spending in Switzerland", Economics Department Working Papers, No. 332. 
Marqués Sevillano, J.M. and J. Rosselló Villalonga (2002), "Public Employment and Redistribution in Spain", Instituto de Estudios Fiscales, Papeles de trabajo, No. 23/02.

Ministerio de Sanidad y Consumo (2003), Recursos económicos del Sistema Nacional de Salud - Datos y Cifras 2003, Madrid, www.msc.es/profesional/sistemasInformacion/analisisEconomico/recursosEconomicos/pdf/libro_rec ursos naranja.pdf.

Monasterio-Escudero, C. and J. Suárez-Pandiello (2002), "Local Government Financing and Borrowing: Spain", Local Public Finance in Europe, Balancing the Budget and Controlling Debt, B. Dafflon (ed.), Studies in Fiscal Federalism and State-Local Finance, Edward Elgar Publishing.

Montero, R., J. de Dios Jiménez and J.J. Martín (2004), "Cuantificación y evaluación del nuevo sistema de financiación autonómico general", Instituto Valenciano de Investigaciones Económicas, Documentos de trabajo, WP-EC 2004-08, Valencia, March, www.ivie.es/downloads/docs/04/wpec08.pdf.

OCDE (2003a), Ageing and Employment Policies: Spain, OECD, Paris, www.oecd.org/els/employment/olderworkers.

OECD (2003b), OECD Economic Surveys: Spain, Vol. 2003/7, OECD, Paris.

OECD (2004), OECD Economic Surveys: Euro area, Vol. 2004/5, OECD, Paris, www.oecd.org/eco/surveys/euroarea.

OECD (2005), OECD Economic Surveys: Spain, Vol. 2005/6, OECD, Paris.

Poveda Blanco, F. and Á. Sánchez Sánchez (2002), "La financiación impositiva municipal: propuestas para su reforma", Papeles de Economía Española, No. 92, Fundación de las Cajas de Ahorros

Confederadas, Madrid, www.funcas.ceca.es/Publicaciones/Papeles_Economia_Espanola.asp.

Salinas Jiménez, J. and S. Álvarez García (2002), "El endeudamiento de las Comunidades Autónomas: de la LOFCA a la LGEP”, Instituto de Estudios Fiscales.

Sánchez Soliño, A. (2003), "Estructura de las haciendas locales y valoración de su reciente reforma", EC/2003/3, Servicio de Estudio, Bank of Spain.

le Saout, R. (1998), Les enjeux de l'intercommunalité, La documentation française, Paris, www.ladocumentationfrancaise.fr/catalogue/3303332108114/index.shtml.

SIMEG (Sindicato Médico de Granada) (2004), Estudio comparativo del salario del médico en España, Granada, May, www.simeg.org/modelo\%20retributivo/estudio\%202004.pdf.

Solé-Ollé, A. and N. Bosch (2003), "On the Relationship between Local Authority Size and Expenditure: Lessons for the Design of Intergovernmental Transfers in Spain”, in G. Färber and N. Otter (eds.), Reforms of Local Fiscal Equalization in Europe, Speyerer Forschungsberichte, No. 232, Forschungsinstitut für Öffentliche Verwaltung, Speyer am Rhein, http://foev.dhvspeyer.de/publikationen/pubdb.asp?reihen_id=1. 


\section{WORKING PAPERS}

The full series of Economics Department Working Papers can be consulted at www.oecd.org/eco/Working_Papers/

435. Sources of inflation persistence in the euro area

(July 2005) Boris Cournède, Alexandra Janovskaia, Paul van den Noord

434. Measuring Cyclically-Adjusted Budget Balances for OECD Countries

(July 2005) Nathalie Girouard and Christophe André

433. Product Market Competition and Economic Performance in the United Kingdom (June 2005) Maria Maher and Michael Wise

432. The Benefits of Liberalising Product Markets and Reducing Barriers to International Trade and Investment: the Case of the United States and the European Union (May 2005)

431. Boosting Growth through Greater Competition in Denmark (May 2005) Martin Jørgensen

430. Fifteen Years of Economic Reform in Russia: What Has Been Achieved: What Remains to be Done? (May 2005) Rudiger Ahrend and William Tompson

429. Assessing the OECD Job Strategy: Past Developments and Reforms (May 2005) Nicola Brandt, Jean-Marc Burniaux and Romain Duval

428. Ageing, Welfare Services and Municipalities in Finland (May 2005) Jens Lundsgaard

427. The Impact of Structural Policies on Trade-Related Adjustment and the Shift to Services (April 2005) Per Mathis Kongsrud and Isabelle Wanner

426. Product Market Competition and Economic Performance in Iceland (April 2005) Thomas Laubach and Michael Wise

425. Enhancing Brazil's Regulatory Framework for Network Industries: The Case of Electricity, Oil and Gas, and Water and Sanitation (April 2005) Edmar Almeida and Nanno Mulder

424. Education Attainment in Brazil: The Experience of FUNDEF (April 2005) Luiz de Mello and Mombert Hoppe

423. Estimating a Fiscal Reaction Function: The Case of Debt Sustainability in Brazil (April 2005) Luiz de Mello

422. Product Market Competition and Economic Performance in the Netherlands (April 2005) Maria Maher and Michael Wise

421. Product Market Competition and Economic Performance in Canada (April 2005) Maria Maher and Jay Shaffer

420. The Impact of Ageing on Demand, Factor Markets and Growth (April 2005) Joaquim Oliveira Martins, Frédéric Gonand, Pablo Antolin, Christine de la Maisonneuve and Kwang-Yeol Yoo. 
419. Product Market Regulation in OECD Countries: 1998 to 2003

(February 2005) Paul Conway, Véronique Janod and Giuseppe Nicoletti

418. Reforming Turkey's Public Expenditure Management (February 2005) Rauf Gönenç, Willi Leibfritz and Erdal Yilmaz

417. Fiscal Gimmickry in Europe: One-Off Measures and Creative Accounting (February 2005) Vincent Koen and Paul van den Noord

416. Getting the Most out of Public Sector Decentralisation in Japan (January 2005) Isabelle Joumard and Tadashi Yokoyama

415. Structural Policy Reforms and External Imbalances (January 2005) Mike Kennedy and Torsten Sløk

414. The Jobs Challenge in Poland: Policies to Raise Employment (January 2005) Andrew Burns and Przemyslaw Kowalski

413. Product Market Competition and Economic Performance in Finland (December 2004) Jens Høj and Michael Wise

412. Oil Price Developments: Drivers, Economic Consequences and Policy Responses (December 2004) Anne-Marie Brook, Robert Price, Douglas Sutherland, Niels Westerlund and Christophe André

411. Wealth Effects on Money Demand in EMU: Econometric Evidence (November 2004) Laurence Boone, Fanny Mikol and Paul van den Noord

410. Banking Reform in Russia : Problems and Prospects (November 2004) William Tompson

409. Public Expenditure in France (November 2004) Andrew Burns and Alessandro Goglio

409 La gestion des dépenses publiques en France (Novembre 2004) Andrew Burns et Alessandro Goglio

408. Russian Industrial Restructuring: Trends in Productivity, Competitiveness and Comparative Advantage (October 2004) Rudiger Ahrend

407. Improving the Capacity to Innovate in Germany (October 2004) Andrés Fuentes, Eckhard Wurzel and Margaret Morgan

406. Tax Treatment of Private Pension Savings in OECD Countries and the Net Tax Cost per Unit of Contribution to Tax-Favoured Schemes (October 2004) Kwang-Yeol Yoo and Alain de Serres

405. The Reform of the Health Care System in Portugal (October 2004) Stéphanie Guichard

404. Accounting for Russia's Post-Crisis Growth (October 2004) Rudiger Ahrend

403. Restructuring Russia's Electricity Sector: Towards Effective Competition or Faux Liberalisation? (October 2004) William Tompson 